WRI-97-R033

\title{
NOX EMISSIONS PRODUCED WITH COMBUSTION OF POWDER RIVER BASIN COAL IN A UTILITY BOILER
}

Topical Report

March 1996 - March 1997

By

John S. Nordin

Norman W. Merriam

April 1997

Work Performed Under Cooperative Agreement

DE-FC21-93MC30127 Task 9

For

U.S. Department of Energy

Office of Fossil Energy

Federal Energy Technology Center

Morgantown, West Virginia

By

Western Research Institute

Laramie, Wyoming 


\section{DISCLAIMER}

Portions of this document may be illegible in electronic image products. Images are produced from the best available original document. 


\section{DISCLAIMER}

This report was prepared as an account of work sponsored by an agency of the United States Government. Neither the United States Government nor any agencies thereof, nor any of its employees makes any warranty, expressed or implied, or assumes any legal liability or responsibility for the accuracy, completeness, or usefulness of any information, apparatus, product, or process disclosed or represents that its use would not infringe on privately owned rights. Reference herein to any specific commercial product, process, or service by trade name, trademark, manufacturer, or otherwise does not necessarily constitute or imply endorsement, recommendation, or favoring by the United States Government or any agency thereof. The views and opinions of authors expressed herein do not necessarily state or reflect those of the United States Government or any agency thereof. 


\section{TABLE OF CONTENTS}

LIST OF TABLES AND FIGURES ……………....................................................... iii

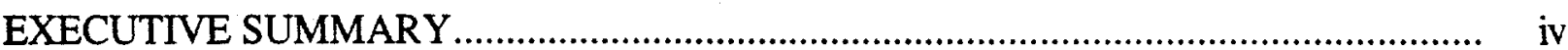

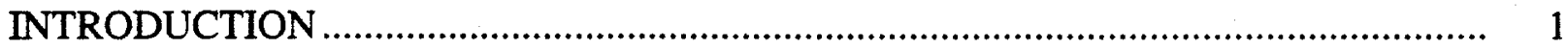

THEORY OF NOX FORMATION DURING COMBUSTION .........................................

General Comments ..............................................................................................

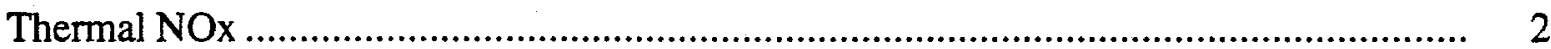

Prompt NOx.............................................................................................................. 3

COAL NTTROGEN NOx............................................................................................ 3

Effect of Mineral Content on NOx Emissions .............................................................. 6

Formation of $\mathrm{N}_{2} \mathrm{O}$ from Coal Nitrogen in Fluidized Bed Combustors .............................. 9

NOx LAWS AND REGULATIONS FOR COAL-FIRED ELECTRIC POWER PLANTS .. 14

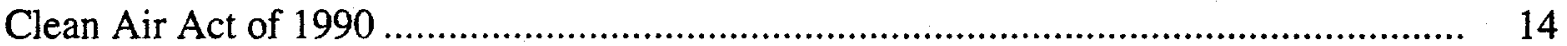

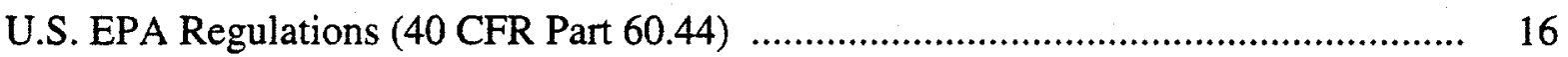

Determination of NOx Emission Rates.................................................................. 17

POWER PLANT COMPLIANCE WITH NOX EMISSION LIMITS ............................... 18

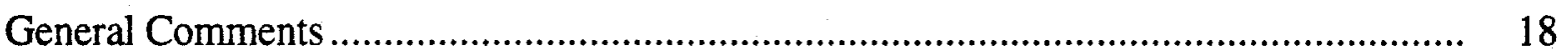

Keeping the Furnace Clean ................................................................................... 19

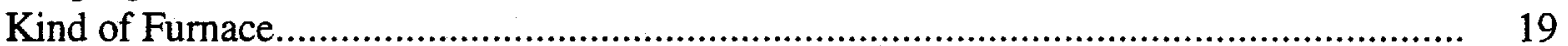

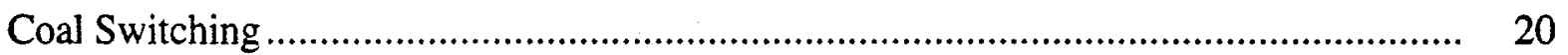

Tight Computerized Combustion Control ............................................................... 20

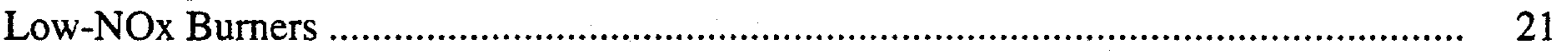

Natural Gas Co-Firing and Reburning...................................................................... 25

Selective Catalytic Reduction (SCR) ….................................................................. 26

Selective Non-Catalytic Reduction (SNCR) ................................................................. 27

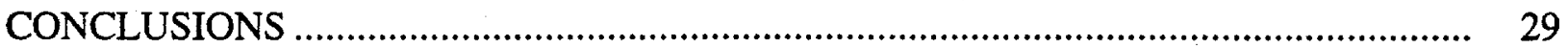

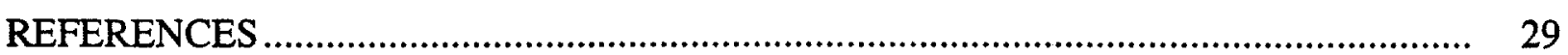




\section{LIST OF TABLES}

$\underline{\text { Table }}$

Page

1 Nitrogen Functionality for Selected U.S. Coals ...................................................... 4

2 Composition of Coal Ashes ................................................................................ 6

3 List of Major Researchers With Supporting Institutions and Publication Interests..... 10

4 Phase I NOx Emission Limits Specified in the Clean Air Act.................................... 14

5 Phase II NOx Emission Limits Specified in the Clean Air Act.................................... 15

6 National Ambient Air Quality Standards for NOx, Ozone, and Particulates ............. 15

7 EPA NOx Emission Limits Specified in 40 CRF Part 60.44a for Utilities Combusting More Than 250 Million Btu/hr of Fossil Fuel ..................................................... 16

8 EPA NOx Emission Limits Specified in 40 CFR Part 60.44b for Utilities Combusting Between 100 and 250 Million Btu/hr of Fossil Fuel ............................................. 17

$9 \quad$ F Factor for Converting dscf to mm Btu .......................................................... 18

10 Typical Processed PRB Coal .......................................................................... 19

11 Comparison of NOx Emissions from Combusting Four Different Coals.................... 20

12 Low-NOx Burner Retrofit Coal-Fired Utility Boiler Published Examples ................. 22

13 Published Examples of Gas Reburning ............................................................ 26 


\section{EXECUTIVE SUMMARY}

Nitric oxide (and nitrous oxide) emissions from coal-fired utilities depend primarily on how the coal is burned and to a lesser extent on the nitrogen content of the coal itself, even though most of the NOx produced originates from coal nitrogen. With a combination of tight, computerized combustion control, including controlling temperatures and the use of low-NOx burners utilities should be able to meet the Clean Air Act Title IV NOx limits. For tangentially fired boilers the limits are $0.45 \mathrm{lb} / \mathrm{mm}$ Btu (Phase I) and $0.40 \mathrm{lb} / \mathrm{mm}$ Btu (Phase II). For drybottom, wall-fired boilers the limits are $0.50 \mathrm{lb} / \mathrm{mm}$ Btu (Phase 1) and $0.46 \mathrm{lb} / \mathrm{mm}$ BTU (Phase II). Compliance for phase I is January 1996; compliance for phase II is January 2000. Emission limits for these laws and regulations are expressed as equivalent $\mathrm{NO}_{2}$ even though nitric oxide (NO), and to a much lesser extent nitrous oxide $\left(\mathrm{N}_{2} \mathrm{O}\right)$, are the chemical species actually emitted. Local and regional regulatory agencies may place more stringent limits on utility NOx emissions than the Title IV standards in an effort to meet ambient air quality standards, especially in ozone nonattainment areas.

Powder River Basin (PRB) coal offers an advantage for utilities meeting NOx limitations because it is a more reactive coal and when burned in a utility boiler fitted with low-NOx burner technology can produce $20 \%$ less NOx than burning an eastern bituminous coal. While this may not seem like a major improvement, because the U.S. Environmental Protection Agency (EPA) has set Phase II limits near what low-NOx burner and tight combustion control is technically capable of achieving, any improvement will help. This is providing, however, that the furnace is clean and well maintained, as a dirty furnace with slag buildup will result in higher burning temperatures and increased NOx. Burning PRB coal can result in more furnace slag buildup than when burning eastern coals. This buildup is not easily removed with soot blowers; frequent cleaning with waterlances is required.

Nevertheless, in laboratory and in pilot plant demonstrations using more reactive, subbituminous coals NOx emissions have been lower than those from bituminous coals. NOx emissions lower than those from eastern coals have also been demonstrated in power plants burning PRB coal. The greater reactivity is related to the higher quaternary nitrogen functionally (compared with pyridinic and pyrolic nitrogen functionality) of subbituminous coal (including PRB coal), which produces less NOx when burned in low-NOx burners. The term "quaternary" does not mean a four-ring structure but refers to what is believed to be a six-ring structure containing nitrogen with oxygen as part of the ring. This report reviews laboratory and pilot plant work on NOx emissions related to coal nitrogen structure, as well as the experience of utility with NOx emissions burning PRB coal. 


\section{INTRODUCTION}

The objective of this report is to estimate the NOx emissions produced when Powder River Basin (PRB) coal is combusted in a utility boiler. The Clean Air Act regulations specify NOx limits of $0.45 \mathrm{lb} / \mathrm{mm}$ Btu (Phase I) and $0.40 \mathrm{lb} / \mathrm{mm}$ Btu (Phase II) for tangentially fired boilers, and $0.50 \mathrm{lb} / \mathrm{mm}$ Btu (Phase I) and $0.46 \mathrm{lb} / \mathrm{mm}$ Btu (Phase II) for dry-bottom wall-fired boilers. The Clean Air Act regulations also specify other limits for other boiler types. Compliance for Phase I has been in effect since January 1, 1996. Compliance for Phase II goes into effect on January 1, 2000. Emission limits are expressed as equivalent $\mathrm{NO}_{2}$ even though $\mathrm{NO}$ (and sometimes $\mathrm{N}_{2} \mathrm{O}$ ) is the NOx species emitted during combustion. Regulatory agencies usually set even lower NOx emission limits in ozone nonattainment areas.

In preparing this report, Western Research Institute (WRI) used published test results from utilities burning various coals, including PRB coal, using state-of-the art control technology for minimizing NOx emissions. Many utilities can meet Clean Air Act NOx emission limits using a combination of tight combustion control and low-NOx burners and by keeping furnaces clean (i.e., no slag buildup). In meeting these limits, some utilities also report problems such as increased carbon in their fly ash and excessive furnace tube corrosion. This report discusses utility experience.

The theory of NOx emission formation during coal combustion as related to coal structure and how the coal is combusted is also discussed. From this understanding, projections are made for NOx emissions when processed PRB coal is combusted in a test similar to that done with other coals. As will be shown, there are a lot of conditions for achieving low NOx emissions, such as tight combustion control and frequent waterlancing of the furnace to avoid buildup of deposits.

\section{THEORY OF NOX FORMATION DURING COMBUSTION}

\section{General Comments}

Essentially all NOx emitted during combustion of coal is nitric oxide (NO). Two important exceptions are (1) combustion of coal in fluidized beds and (2) urea injection into a coal-fired furnace, either of which results in some nitrous oxide $\left(\mathrm{N}_{2} \mathrm{O}\right)$ which is emitted from the stack. The $\mathrm{N}_{2} \mathrm{O}$ concentration in the stack resulting from normal combustion of pulverized coal is in the 1 to $5 \mathrm{ppm}$ range compared with several hundred parts per million of $\mathrm{NO}$, but $\mathrm{N}_{2} \mathrm{O}$ concentration from fluidized bed combustion is in the 20 to $250 \mathrm{ppm}$ range (Wójtowicz et al. 1993). Nitrogen dioxide $\left(\mathrm{NO}_{2}\right)$ is not formed during normal coal combustion but is formed later 
when the stack gas is cooled and NO reacts with air oxygen. Rapid quenching of combustion products promotes large concentrations of $\mathrm{NO}_{2}$ ( $\mathrm{Lin}$ 1996). While the lifetime of $\mathrm{NO}$ and $\mathrm{NO}_{2}$ may be in the order of days, $\mathrm{N}_{2} \mathrm{O}$ is persistent in the atmosphere and is an important greenhouse gas. Regardless of the form of NOx emitted, U.S. government regulations are in terms of equivalent $\mathrm{NO}_{2}$.

Formation of NOx is due to three mechanisms: (1) thermal NOx , (2) prompt NOx, and (3) fuel nitrogen. Coal nitrogen contributes between $50 \%$ to perhaps up to $95 \%$ of the total NOx, depending on how the coal is burned. The NOx derived from coal nitrogen may be either produced from homogeneous gas phase reactions through $\mathrm{HCN}$ and $\mathrm{NH}_{3}$ intermediates or from heterogeneous reactions taking place on the coal char surface. To complicate the picture, NO produced from homogeneous reactions can be reduced to $\mathrm{N}_{2}$ by contact with coal char carbon. At this time, it is not possible to predict NOx emissions for a practical coal combustion situation based on solving individual reaction rate equations, even using computers, although there have been attempts reported in the literature. While the gas phase reaction rate constants have been worked out, the heterogeneous reactions taking place on the char surface have not been described for general situations. Reaction rates on char surfaces are strongly influenced by the mineral content, especially iron and trace metals.

Yang and Puri 1993 have published a list of reaction rate constants for 234 homogeneous gas phase reactions involving combustion of hydrocarbons and interactions with nitrogen. Additional rate constants are in Zabarnick 1992. Chen et al. 1996 have used these rate constants and derived a fuel-NO rate expression for the homogeneous gas phase combustion, applicable for reburning situations. Chen et al. 1996 also caution that formation and destruction rates of NOx are the same magnitude as turbulent mixing rates, and the equilibrium assumption usually done to simplify the mathematics is inadequate when calculating NOx concentrations. It is not possible with today's knowledge to fully describe coal combustion and predict a NOx emission using mathematical relationships, mainly because of lack of information on heterogeneous reactions.

\section{Thermal NOx}

Significant thermal NOx only occurs at high flame temperatures $\left(>2300^{\circ} \mathrm{F}\right.$ or $\left.1260^{\circ} \mathrm{C}\right)$. It is formed by reaction of oxygen and nitrogen in the air. Generation of thermal NOx is exponentially dependent on temperature and square-root dependent on oxygen. Roughly 40 times the amount of $\mathrm{NOx}$ is produced at $2700^{\circ} \mathrm{F}$ than at $2250^{\circ} \mathrm{F}$, for example (Colannino 1993). Minimization of thermal NOx involves reducing the peak flame temperature and lowering oxygen concentrations near the flame zone. Most thermal NOx is formed at the portion of flame close to the burner, where oxygen and peak flame temperature is the highest. With good furnace and burner design, thermal NOx formation during coal combustion can be kept very low. Thermal 
NOx formation during coal combustion becomes significant in tight furnaces such as with cyclone furnaces or furnaces with significant slag buildup, either of which result in higher temperatures.

\section{Prompt NOx}

Prompt NOx is formed from reaction of hydrocarbons with air nitrogen and oxygen. It is created from partial-combustion products such as $\mathrm{CH}$ - very close to the flame front, and forms at temperatures cooler than those for thermal NOx. It is not possible with present burner technology to completely eliminate prompt NOx; the first 15 to $20 \mathrm{ppm}$ of NOx generated during combustion of hydrocarbons, including coal, is due to prompt NOx (Colannino 1993). The use of oxygenated fuels, such as methanol and ethanol, reduces prompt NOx when burning gasoline. The primary NOx formation route when burning natural gas is prompt NOx.

Dupont et al. 1993 reviewed the formation of NOx in natural gas flames, including publication of rate constants. The principal prompt NOx route is through the reaction

$$
\mathrm{CH}+\mathrm{N}_{2} \rightarrow \mathrm{HCN}+\mathrm{N}
$$

which is followed by

$$
\begin{aligned}
& \mathrm{N} \cdot+\mathrm{O}_{2} \rightarrow \mathrm{NO}+\mathrm{O} . \\
& \mathrm{N} \cdot+\mathrm{CH}_{3} \cdot \rightarrow \mathrm{HCN}+\mathrm{H}_{2}
\end{aligned}
$$

The $\mathrm{HCN}$ converts to $\mathrm{NO}$ and $\mathrm{N}_{2}$ (see reactions for $\mathrm{HCN}$ under coal nitrogen). The $\mathrm{CH}$. is formed in the burning process (e.g. $\mathrm{CH}_{4}+\mathrm{OH} \cdot \rightarrow \mathrm{CH}_{3} \cdot+\mathrm{H}_{2} \mathrm{O} ; \mathrm{CH}_{3} \cdot+\mathrm{OH} \cdot \rightarrow \mathrm{CH}_{2} \cdot+$ $\mathrm{H}_{2} \mathrm{O}$; etc.).

\section{Coal Nitrogen NOx}

When coal is combusted, the nitrogen portion is converted to nitric oxides and nitrogen gas. The fraction of NOx nitrogen to total nitrogen in the coal depends primarily on how the coal is burned and to a relatively minor degree on the coal itself. Unlike thermal and prompt NOx, coal nitrogen NOx can form at temperatures as low as $700^{\circ} \mathrm{C}\left(1292^{\circ} \mathrm{F}\right)$. Cai et al. 1993 estimate that under conventional power station firing conditions, 15 to $30 \%$ of the coal nitrogen is typically converted to NOx.

Coal is composed of a mixture of minerals and an organic portion called marcerals. Both are heterogeneous and differ widely among coals. Marcerals are composed of carbon, hydrogen, and oxygen atoms plus some sulfur and nitrogen bound in a macromolecular network, usually in 
the form of aromatic ring clusters with small peripheral groups linked by bridges plus long-change aliphatics. Marcerals may also contain unbound guest molecules. Coal can be physically separated into marceral components by density gradient centrifugation of the pulverized coal using cesium chloride solution as the flotation medium. Coal nitrogen exists in the marceral portion either as part of six-ring structures (pyridinic), five-ring structures (pyrrolic), quaternary, or as amino-type side chains. The distinction between quaternary and amino-type side chains is not really clear in the literature. Most of the references to amino-type side chains are for peats and European brown coals. The existence of amino-type side chains is neither confirmed nor disproven for U.S. coals, according to Kelemen et al. 1994, although some U.S. coals probably contain a small amount.

Using a technique called X-ray photoelectron spectroscopy, a number of researchers (e.g. Kambara et al. 1995; Kelemen et al. 1994) have determined the relative amounts of coal nitrogen in quaternary, pyrrolic, and pyridinic groups. The chemical structure of quaternary forms is not clear; Kelemen et al. 1994 have suggested (at least for Wyodak and Illinois No. 6 coals) that the quaternary-type nitrogen species may be pyridinic forms associated with oxygen fuctionalities that can be easily broken during mild pyrolysis. Examples of nitrogen forms for different coals are shown in Table 1.

Table 1. Nitrogen Functionality for Selected U.S. Coals

\begin{tabular}{|l|l|l|l|l|l|l|}
\hline Coal & $\begin{array}{c}\text { \% N } \\
\text { (dry, } \\
\text { ash-free } \\
\text { basis) }\end{array}$ & $\begin{array}{c}\text { Proximate } \\
\text { wt \% volatile } \\
\text { (dry basis) }\end{array}$ & $\begin{array}{c}\text { Proximate } \\
\text { wt \% fixed } \\
\mathrm{C} \\
\text { (dry basis) }\end{array}$ & $\begin{array}{c}\text { \% of total } \\
\mathrm{N} \text { as } \\
\text { quaternary }\end{array}$ & $\begin{array}{c}\text { \% of total } \\
\mathrm{N} \text { as } \\
\text { pyrrolic }\end{array}$ & $\begin{array}{c}\text { \% of total } \\
\mathrm{N} \text { as } \\
\text { pyridinic }\end{array}$ \\
\hline Roshell & 1.1 & 43.5 & 51.4 & 11.6 & 59.2 & 29.2 \\
\hline Usibelli & 0.9 & 48.8 & 43.0 & 14.2 & 52.8 & 33.1 \\
\hline Beulah Zap & 1.15 & 44.9 & 46.5 & 16 & 59 & 25 \\
\hline Wyodak & 1.12 & 44.7 & 46.5 & 15 & 60 & 25 \\
\hline Illinois No.6 & 1.37 & 40.1 & 44.4 & 12 & 62 & 26 \\
\hline Blind Canyon & 1.57 & 45.8 & 49.5 & 14 & 55 & 31 \\
\hline Pittsburgh No. 8 & 1.64 & 37.8 & 53.0 & 7 & 61 & 32 \\
\hline Pocahontas & 1.33 & 18.6 & 76.6 & 3 & 64 & 33 \\
\hline
\end{tabular}

The percentage of pyridinic nitrogen increases with coal rank. Lower ranked coals have a higher percentage of quaternary nitrogen. Quaternary nitrogen is the least stable, and pyridinic nitrogen is the most stable when the coal is heated.

When pulverized coal is combusted, a number of complicated reactions take place. Researchers studying pyrolysis and combustion of coal differ as to details, but basically the coal nitrogen is converted to ammonia $\left(\mathrm{NH}_{3}\right)$, hydrogen cyanide $(\mathrm{HCN})$, and char nitrogen (char-N) 
intermediates, which in turn are converted to nitric oxide (NO), nitrous oxide $\left(\mathrm{N}_{2} \mathrm{O}\right)$, and nitrogen $\left(\mathrm{N}_{2}\right)$. Quaternary and amino-side chain nitrogen produce $\mathrm{NH}_{3}$ as an intermediate, but pyridinic nitrogen produces char-N and $\mathrm{HCN}$. The fate of pyrrolic nitrogen is less clear, but there is evidence (Kambara et al. 1995) that it produces mostly char-N and $\mathrm{HCN}$ and possibly some $\mathrm{NH}_{3}$. Pyrolysis studies (Varey et al. 1996; Bassilakis et al. 1993) have also demonstrated that rapid heating and higher temperatures favor more $\mathrm{HCN}$, but slower heating and lower temperatures favor more $\mathrm{NH}_{3}$ as an intermediate. Wójtowicz et al. 1995 has found that pyrrolic nitrogen going through the $\mathrm{HCN}$ and char- $\mathrm{N}$ route is first converted to a pyridinic group and that char-N is a 6ring structure mostly of carbon atoms but with the volatile component removed.

Nitrogen oxides and molecular nitrogen may be produced either as a homogenous, gas phase reactions or as heterogeneous reactions involving the coal char surface. The most important reactions on the char surface are

$$
\begin{aligned}
& \mathrm{C}-\text { (char) }+1 / 2 \mathrm{O}_{2} \rightarrow \mathrm{CO}-\text { (char) } \\
& \mathrm{N}-(\text { char })+1 / 2 \mathrm{O}_{2} \rightarrow \mathrm{NO}+(\text { char }) \\
& \mathrm{NO}+2 \mathrm{CO}-(\text { char }) \rightarrow \mathrm{N}_{2}+2 \mathrm{CO}_{2}+\text { (char) }
\end{aligned}
$$

In the gas phase, fuel-lean conditions favor the formation of NO from $\mathrm{HCN}$ :

$$
\begin{aligned}
& \mathrm{HCN}+\mathrm{O} \cdot \leftrightarrow \mathrm{NCO}++\mathrm{H} \cdot \\
& \mathrm{HCN}+\mathrm{O} \cdot \leftrightarrow \mathrm{NH} \cdot+\mathrm{CO} \\
& \mathrm{HCN}+\mathrm{O} \cdot \leftrightarrow \mathrm{CN} \cdot+\mathrm{OH} \cdot \\
& \mathrm{NCO}+\mathrm{O} \cdot \leftrightarrow \mathrm{NO}+\mathrm{CO} \\
& \mathrm{NH}+\mathrm{OH} \cdot \leftrightarrow \mathrm{NO}+\mathrm{H}_{2} \mathrm{O} \\
& \mathrm{CN} \cdot+\mathrm{O} \cdot \leftrightarrow \mathrm{CO} .
\end{aligned}
$$

Fuel-rich conditions favor $\mathrm{N}_{2}$ from $\mathrm{HCN}$ :

$$
\begin{aligned}
& \mathrm{HCN}+\mathrm{OH} \cdot \rightarrow \mathrm{NH}_{2} \cdot+\mathrm{CO} \\
& \mathrm{NH}_{2}+\mathrm{RH} \cdot \rightarrow \mathrm{NH}_{3}+\mathrm{R} \cdot \quad\left(\mathrm{R}=\mathrm{C}, \mathrm{CH}, \mathrm{CH}_{2} \mathrm{CH}, \text { etc. }\right) \\
& \mathrm{NH}_{2} \cdot+\mathrm{NO} \rightarrow \mathrm{N}_{2}+\mathrm{H}_{2} \mathrm{O} \\
& \mathrm{CH} \cdot+\mathrm{NO} \rightarrow \mathrm{HCN}+\mathrm{O} .
\end{aligned}
$$


A similar set of reactions can be written for $\mathrm{NH}_{3}$, with fuel-lean conditions favoring $\mathrm{NO}$ and fuel-rich conditions favoring $\mathrm{N}_{2}$.

In addition, $\mathrm{HCN}$ can react with coal hydrogen in the coal pores to form $\mathrm{NH}_{3}$ (Bassilakis et al. 1993). A slower coal heating rate allows more time for this reaction to take place. Rapid heating during pyrolysis produces more $\mathrm{HCN}$, but slower heating produces more $\mathrm{NH}_{3}$.

In reburning schemes, a small amount of secondary fuel is injected into the products from the main combustion zone. The secondary fuel could be pulverized coal, but some utilities use natural gas, which does not contain fuel nitrogen. The natural gas portion typically represents 10 to $20 \%$ of the total fuel burned on a heat content basis. When natural gas is burned, hydrocarbon free radicals are formed, which react with NO produced in the primary combustion zone.

$$
\begin{aligned}
& \mathrm{NO}+\mathrm{CH} \cdot \rightarrow \mathrm{HCN}+\mathrm{O} \\
& \mathrm{NO}+\mathrm{CH}_{2} \cdot \rightarrow \mathrm{NCO}+\mathrm{H}_{2} \\
& \mathrm{NO}+\mathrm{CH}_{3} \cdot \rightarrow \mathrm{HCN}+\mathrm{H}_{2} \mathrm{O}
\end{aligned}
$$

The $\mathrm{HCN}$ formed may then react to form $\mathrm{N}_{2}$ under oxygen-lean conditions or it may reform NO if the oxygen concentration is too high.

Niksa and Cho 1996 of SRI International concluded after studying conversion of fuel nitrogen in pulverized coal flames that NO production shuts down if hydrocarbons are present but become the main coal- $\mathrm{N}$ conversion channel in their absence. The inception point for NO production is determined by consumption of $\mathrm{O}_{2}$ among all fuel components including soot and char. As long as there are hydrocarbon radicals present, $\mathrm{N}_{2}$ is the only stable product of fuel-N conversion.

German researchers (Spliethoff et al. 1996) studying coal reburning (also called fuel staging) reported that increased residence time in the primary zone reduces NOx emissions, leading to optimum reburning (minimum NOx) under fuel-lean conditions. They also reported that more reactive European brown coals produced less NOx emission than bituminous coals, and the $\mathrm{NH}_{3}$ intermediate produced less $\mathrm{NOx}$ than the $\mathrm{HCN}$ intermediate, all under fuel staging conditions. As verified by other researchers, the authors found NOx emissions increase with temperature and with increased air. German utilities (Maier et al. 1994) have reduced NOx emissions by a factor of two $\left(-400 \mathrm{ppm}\right.$ to $\sim 200 \mathrm{ppm}$ at $\left.6 \% \mathrm{O}_{2}\right)$ by using reburning.

Low-NOx burners work on the principle of controlling combustion by staging air introduction to the flame to ensure that the primary burning zone takes place under air-starved 
(fuel-rich) conditions. The air is added in several stages and/or fuel is added in two stages to ensure that hydrocarbon radicals are present to react with nitric oxide without resulting in unburned carbon in the ash. Coal-fired utility (tangentially fired) boilers using low-NOx burners have successfully reduced NOx emissions to the 0.35 to $0.5 \mathrm{lb}$ NOx/mm Btu range.

Wang et al. 1996 has commented that low-NOx burners have successfully reduced thermal and prompt and gas-phase, fuel-derived NOx emissions but are not very successful in reducing the char-N component. Wang et al. 1996 estimate that 60 to $90 \%$ of the NOx left after installation of low-NOx burners originates from the char-N component. Cai et al. 1993 say the same, estimating 60 to $95 \%$ of NO originates from cnar-N when using low-NOx burners. This compares with 60 to $80 \%$ NOx emissions derived from gas phase reactions when low-NOx burner technology is not used during pulverized coal combustion (Wang et al. 1994). The char- $\mathrm{N}$ can be combusted to $\mathrm{N}_{2}$ or $\mathrm{NO}$, and $\mathrm{NO}$ formed previously can be reduced by carbon char to $\mathrm{N}_{2}$. Higher-ranked coals formed more NO from coal-N, and lower ranked coals formed more $\mathrm{N}_{2}$, when different coal chars were combusted in an entrained flow test reactor. The authors (Wang et al. 1996) attributed this to a greater surface area (from volatiles leaving the coal), allowing NO to be reduced on the surface or in the pores of the char.

Varey et al. 1996 looked at NO formation during combustion of different coals in a temperature-programmed reactor using $20 \%$ oxygen and $80 \%$ helium as the combustion gas, with sampling of pyrolysis intermediates and NO directly above the sample. The NO-to-coal nitrogen ratio $(\mathrm{NO} / \mathrm{N})$ increased significantly with temperature at $50 \%$ burnoff. The authors classified the various coals into marceral density fractions, with vitrinite being the most reactive and having the lowest temperature at $50 \%$ burnoff. Fusinite was the least reactive marceral and had the highest temperature at $50 \%$ burnoff and highest NO/N. Vitrinite char was more reactive and led to a greater reduction of $\mathrm{NO}$ to $\mathrm{N}_{2}$ on its surface. The Wyodak coal tested had a marceral analysis of $89 \%$ vitrinite and $11 \%$ inertinite (another marceral fraction) by volume.

Niksa and Cho 1996 found that char, soot, and noncondensibles burned simultaneously when a subbituminous coal (Dietz) was burned in a laboratory quartz tube flow reactor. A bituminous coal (Pittsburgh No. 8) char oxidation rate was slower. When the char oxidation rate is comparable to the noncondensible and soot oxidation rates, there are free hydrocarbon radicals to react with any NO produced previously.

Pease et al. 1993 of ABB Power Plant Laboratories (Windsor, Connecticut) advocate preliminary testing of coals in pilot plant setups to access the impacts of utility coal switching from eastern to western low-sulfur subbituminous coals. The authors state that the higher combustion reactivity of subbituminous coal compared to bituminous can be advantageous from a carbon burnout standpoint under low NOx firing applications. 


\section{Effect of Mineral Content on NOx Emissions}

The mineral content of the coal affects the NOx emissions, especially the heterogeneous reactions taking place on the char surface during burning. The minerals act as catalysts promoting a particular conversion pathway rather than taking part directly. This is one area where reaction rate constants have not been determined, and therefore it is not possible with today's technology to develop a computer program to predict NOx emissions for a given coal and burning configuration.

A high iron content promotes the conversion of coal nitrogen to $\mathrm{N}_{2}$ rather than to $\mathrm{NO}$, for example. Ohtsuka et al. 1993 and Mori et al. 1996 demonstrated that $\mathrm{N}_{2}$ formation from coal nitrogen was greatly promoted when various pulverized coals were doped with iron from precipitated $\mathrm{FeCl}_{3}$ solutions and pyrolyzed in a fluidized bed reactor. During pyrolysis tests in a helium atmosphere at $900^{\circ} \mathrm{C}, 50$ to $60 \%$ of the coal nitrogen was converted to $\mathrm{N}_{2}$ rather than $\mathrm{HCN}$ and $\mathrm{NH}_{3}$ when the raw coal was doped with 3 to $7 \%$ iron, compared with about $3 \%$ conversion to $\mathrm{N}_{2}$ without the iron. Even at $0.73 \%$ iron, the amount of $\mathrm{N}_{2}$ formed relative to $\mathrm{HCN}$ and $\mathrm{NH}_{3}$ under pyrolysis conditions was 12 times that for a test run with no iron added. The nitrogen content of the chars with iron following pyrolysis was either the same or lower than chars produced without iron (depending on the coal).

Leppälahi et al. 1991 also found under pyrolysis conditions at $900^{\circ} \mathrm{C}$ that the presence of iron catalyzed the destruction of $\mathrm{NH}_{3}$ and $\mathrm{HCN}$ from coal nitrogen, forming $\mathrm{N}_{2}$; the authors also found that limestone or dolomite added to the raw coal catalyzed the destruction of $\mathrm{HCN}$ but not $\mathrm{NH}_{3}$. At $800^{\circ} \mathrm{C}$, iron was much less effective in catalyzing the destruction of $\mathrm{NH}_{3}$ and $\mathrm{HCN}$. The iron catalyst was added to the coal as ultrafine particles slurried in an acetone matrix and acetone evaporated. Silica or silicon carbide did not promote the conversion of $\mathrm{NH}_{3}$ and $\mathrm{HCN}$ from coal pyrolysis to $\mathrm{N}_{2}$.

The cationic mineral composition from ash analysis is presented in Table 2 for six different coals. In the original coal, the minerals are present as complexes containing carbonates, bicarbonates, chlorides, and sulfates, but the analyses are reported as equivalent oxides.

Table 2. Composition of Coal Ashes (weight percent expressed as equivalent oxide)

\begin{tabular}{|l|l|l|l|l|l|l|l|l|l|}
\hline Coal & $\mathrm{SiO}_{2}$ & $\mathrm{Al}_{2} \mathrm{O}_{3}$ & $\mathrm{Fe}_{2} \mathrm{O}_{3}$ & $\mathrm{TiO}_{2}$ & $\mathrm{CaO}$ & $\mathrm{MgO}$ & $\mathrm{Na}_{2} \mathrm{O}$ & $\mathrm{K}_{2} \mathrm{O}$ & $\mathrm{P}_{2} \mathrm{O}_{5}$ \\
\hline \hline Beulah Zap & 27.5 & 14.2 & 9.9 & 2.8 & 27.4 & 5.9 & 10.8 & 1.0 & 0.4 \\
\hline Pittsburgh No 8 & 50.8 & 20.2 & 17.5 & 1.3 & 5.2 & 1.3 & 0.0 & 2.5 & 0.2 \\
\hline Ilinois No 6 & 48.6 & 23.1 & 14.3 & 1.2 & 5.8 & 1.6 & 0.5 & 3.1 & 0.3 \\
\hline Indian Head & 36.0 & 22.1 & 2.8 & 1.2 & 24.0 & 5.8 & 1.9 & 0.9 & 0.1 \\
\hline Martin Lake & 33.4 & 19.0 & 10.4 & 1.2 & 29.4 & 5.9 & 1.5 & 0.4 & 0.0 \\
\hline Wyodak & 41.2 & 20.0 & 4.6 & 2.0 & 24.1 & 5.3 & 1.0 & 0.5 & 0.8 \\
\hline
\end{tabular}

Table from Novok et al. 1990. 
There is little published work available on the effect of the mineral composition of a coal on NOx emissions when the coal is burned. For example, on the basis of iron content, one would expect burning Illinois No 6 coal to result in lower NOx emissions than burning Wyodak coal. In fact, pilot plant and utility data show that NOx emissions are primarily affected not by the coal itself but by how the coal is burned and that burning Wyodak coal may even result in slightly lower NOx emissions than Mlinois No 6. This is because Wyodak is a relatively reactive coal with a relatively high quaternary nitrogen functionality.

\section{Formation of $\mathrm{N}_{2} \mathrm{O}$ from Coal Nitrogen in Fluidized Bed Combustors}

Nitrous oxide $\left(\mathrm{N}_{2} \mathrm{O}\right)$ is a persistent greenhouse gas and has been implicated in destruction of stratospheric ozone. According to Wójtowicz 1993, its half life is in the range of 150 to 160 years compared with 0.5 to 5 days for nitric oxide. Almost half of the stratospheric ozone loss is due to $\mathrm{N}_{2} \mathrm{O}$, and a doubling of $\mathrm{N}_{2} \mathrm{O}$ concentration from its current level (as of 1990) of 310 parts per billion (ppb) could decrease stratospheric ozone by $12 \%$.

Nitrous oxide $\left(\mathrm{N}_{2} \mathrm{O}\right)$ emissions may be significant from fluidized bed combustors, with emissions in the range of 20 to $250 \mathrm{ppm}$. According to Amand and Lechner 1993, the dominant $\mathrm{N}_{2} \mathrm{O}$ pathway is through the $\mathrm{HCN}$ intermediate, as follows:

$$
\begin{aligned}
& \mathrm{HCN}+\mathrm{O} \rightarrow \mathrm{NCO}+\mathrm{H} \\
& \mathrm{NCO}+\mathrm{NO} \rightarrow \mathrm{N}_{2} \mathrm{O}+\mathrm{CO}
\end{aligned}
$$

The $\mathrm{NH}_{3}$ intermediate may also form some $\mathrm{N}_{2} \mathrm{O}$ but the yield is smaller than from the $\mathrm{HCN}$ route.

$$
\begin{aligned}
& \mathrm{NH}_{3}+\mathrm{NO} \rightarrow \mathrm{N}_{2} \mathrm{O}+\mathrm{H}_{2} \\
& \mathrm{NH}+\mathrm{NO} \rightarrow \mathrm{N}_{2} \mathrm{O}+\mathrm{H} \cdot
\end{aligned}
$$

Aho et al. 1993 report that high concentrations of $\mathrm{N}_{2} \mathrm{O}$ will form if $\mathrm{HCN}$ is artificially introduced into a post flame environment at temperatures around 730 to $900^{\circ} \mathrm{C}$, but relatively small amounts of $\mathrm{N}_{2} \mathrm{O}$ are formed if $\mathrm{NH}_{3}$ is introduced. Tullin et al. 1993 also add that $\mathrm{N}_{2} \mathrm{O}$ can form from the oxidation of char in the presence of NO. Wójtowicz 1993 estimate that charformed $\mathrm{N}_{2} \mathrm{O}$ contributes about $10 \%$ of the total $\mathrm{N}_{2} \mathrm{O}$ in fluidized bed combustion.

$$
2 \mathrm{NO}+\mathrm{C} \text {-(char) } \rightarrow \mathrm{N}_{2} \mathrm{O}+\mathrm{CO} \text {-(char) }
$$


Nitrous oxide emissions are very much temperature dependent. Nitrous oxide $\left(\mathrm{N}_{2} \mathrm{O}\right)$ emissions significantly decrease with increasing temperature but nitric oxide (NO) emissions significantly increase with temperature. At higher temperatures (Tullin et al. 1993), significant $\mathrm{H}$. and $\mathrm{OH}$. radicals are formed that destroy $\mathrm{N}_{2} \mathrm{O}$. Fluidized bed combustors operate at temperatures of 700 to $900^{\circ} \mathrm{C}$ compared with about $1200^{\circ} \mathrm{C}$ for pulverized coal furnaces; the corresponding $\mathrm{N}_{2} \mathrm{O}$ emissions are typically 50 to $150 \mathrm{ppm}$ for fluidized bed combustors compared with $<5$ ppm for pulverized coal combustors. Graphs of $\mathrm{N}_{2} \mathrm{O}$ and $\mathrm{NO}$ emissions for different coals are presented as a function of temperature in a paper by Collings et al. 1993. Higher ranked coals produce more $\mathrm{N}_{2} \mathrm{O}$ than lower ranked coals, and North Dakota lignites produced more $\mathrm{N}_{2} \mathrm{O}$ than Wyoming subbituminous coals. In their test, the fluidized bed combustor operated at $1120 \mathrm{~K}$ and $20 \%$ excess air combusting PRB coal, and $3.42 \%$ of the fuel nitrogen was converted to $\mathrm{N}_{2} \mathrm{O}$, $8.34 \%$ was converted to $\mathrm{NO}$, and $88.2 \%$ was converted to $\mathrm{N}_{2}$.

Table 3. Major Researchers With Supporting Institutions and Publication Interests

\begin{tabular}{|c|c|c|}
\hline Researchers & Supporting Institution & Publications/Interests \\
\hline $\begin{array}{l}\text { L.D. Smoot } \\
\text { W. Chen } \\
\text { T.H. Fletcher } \\
\text { K.J. Bateman } \\
\text { W.F. Wells } \\
\text { A. U. Blackham } \\
\text { C.R. Monson } \\
\text { G.J. Germane }\end{array}$ & $\begin{array}{l}\text { Brigham Young University, } \\
\text { Provo, Utah }\end{array}$ & $\begin{array}{l}\text { Global Fuel-NO Rate Expressions; NO reburning } \\
\text { mechanisms; effect of pressure on oxidation rate of } \\
\text { chars; relation between coal reactivity and structure; } \\
\text { also paper (Blachkam) on combustion of large char } \\
\text { particles; also paper (Monson and Germane 1993) on } \\
\text { a high-pressure drop tube furnace for coal } \\
\text { combustion studies. }\end{array}$ \\
\hline F. Derbyshire & $\begin{array}{l}\text { University of Kentucky, } \\
\text { Lexington, } \mathrm{KY}\end{array}$ & $\begin{array}{l}\text { Changes in vitrinite structure of coal during thermal } \\
\text { processing }\end{array}$ \\
\hline $\begin{array}{l}\text { S. Eser } \\
\text { R.G. Jenkins } \\
\text { C. Song } \\
\text { H.H. Schobert }\end{array}$ & $\begin{array}{l}\text { Amoco Research Center, } \\
\text { Naperville IL; also } \\
\text { Pennsylvania State Univ. }\end{array}$ & $\begin{array}{l}\text { Changes in Wyodak and Illinois coals during heating } \\
\text { in a helium atmosphere between } 150 \text { and } 1000 \mathrm{psi} \\
\text { (interest is in coal conversion processes, especially } \\
\text { liquefaction) }\end{array}$ \\
\hline $\begin{array}{l}\text { S. Niksa } \\
\text { S. Cho } \\
\end{array}$ & $\begin{array}{l}\text { SRI International, Menlo } \\
\text { Park, CA }\end{array}$ & $\begin{array}{l}\text { NOx formation in pulverized coal flames } \\
\text { (experimental) }\end{array}$ \\
\hline $\begin{array}{l}\text { P.R. Solomon } \\
\text { R. Bassilakis } \\
\text { Y. Zhao } \\
\text { M.A. Serio } \\
\end{array}$ & $\begin{array}{l}\text { Advanced Fuel Research, } \\
\text { Inc., East Hartford, CN }\end{array}$ & $\begin{array}{l}\text { Coal pyrolysis; published data on off-gases when } \\
\text { heating bituminous and lignite in absence of air }\end{array}$ \\
\hline $\begin{array}{l}\text { B.R. Pease } \\
\text { A.A. Levasseur } \\
\text { O.K. Chow }\end{array}$ & $\begin{array}{l}\text { ABB Power Plant } \\
\text { Laboratories, Combustion } \\
\text { Engineering Inc., Windsor } \\
\text { CN }\end{array}$ & $\begin{array}{l}\text { Assessment of coal fuel switching using a pilot plant; } \\
\text { statement made, "The higher combustion reactivity of } \\
\text { subbituminous coal compared with bituminous can be } \\
\text { advantageous from a carbon burnout... under low- } \\
\text { NOx firing applications." }\end{array}$ \\
\hline K.S. Vorres & $\begin{array}{l}\text { Argonne Nat. Lab, } \\
\text { Argonne, IL }\end{array}$ & $\begin{array}{l}\text { drying of Wyodak subbituminous and Beulah-Zap } \\
\text { lignite coals }\end{array}$ \\
\hline
\end{tabular}




\begin{tabular}{|c|c|c|}
\hline Researchers & Supporting Institution & Publications/Interests \\
\hline $\begin{array}{l}\text { W.P. Partridge Jr. } \\
\text { N.M. Lauendeau }\end{array}$ & $\begin{array}{l}\text { Purdue University, } \\
\text { West Lafayette, IN }\end{array}$ & NOx formation in diffusion flames \\
\hline $\begin{array}{l}\text { W.G. Willson } \\
\text { S.A. Farnum } \\
\text { M.E. Collings } \\
\text { M.D. Mann } \\
\text { B.C. Young }\end{array}$ & $\begin{array}{l}\text { University of North } \\
\text { Dakota, Grand Forks, ND }\end{array}$ & $\begin{array}{l}\text { Williams noted that tars emitted under pressure } \\
\text { during heat drying of lignites tend to coat the particle } \\
\text { surface; Collings modeled } \mathrm{N}_{2} \mathrm{O} \text { emissions in } \\
\text { circulating fluidized bed combustion; Mann reviewed } \\
\mathrm{N}_{2} \mathrm{O} \text { emissions testing and abatement }\end{array}$ \\
\hline O.I. Ogunsola & $\begin{array}{l}\text { University of Alaska, } \\
\text { Fairbanks, Alaska }\end{array}$ & $\begin{array}{l}\text { Effect of thermal drying on oxygen functional groups } \\
\text { in lignite (western Canada) }\end{array}$ \\
\hline K. Zygourakis & Rice Univ., Houston TX & Effect of pyrolysis on coal macropore structure \\
\hline $\begin{array}{l}\text { T.L. Yeh } \\
\text { T.C. Keener }\end{array}$ & $\begin{array}{l}\text { University of Cincinnati, } \\
\text { Cincinnati, OH }\end{array}$ & $\begin{array}{l}\text { Use of a heated screw to achieve mild pyrolysis of an } \\
\text { Ohio coal }\end{array}$ \\
\hline $\begin{array}{l}\text { S.R. Keleman } \\
\text { M.L. Gorbaty }\end{array}$ & $\begin{array}{l}\text { Exxon Research and Eng. } \\
\text { Co., Annandale, NJ }\end{array}$ & Nitrogen forms in coal \\
\hline $\begin{array}{l}\text { B.A. Wong } \\
\text { G.R. Gavalas } \\
\text { R.C. Flagan } \\
\end{array}$ & $\begin{array}{l}\text { California Inst. of Tech., } \\
\text { Pasadena, CA }\end{array}$ & Shrinking of porous coal particles during combustion \\
\hline $\begin{array}{l}\text { A. Atal } \\
\text { Y.A. Levendis }\end{array}$ & $\begin{array}{l}\text { Northeastern University, } \\
\text { Boston, MA }\end{array}$ & $\begin{array}{l}\text { Combustion behavior of coal and waste automobile } \\
\text { tires }\end{array}$ \\
\hline $\begin{array}{l}\text { A.F. Sarofim } \\
\text { S. Goel }\end{array}$ & $\begin{array}{l}\text { Mass. Inst. of Tech., } \\
\text { Cambridge, MA }\end{array}$ & $\begin{array}{l}\text { NO and } \mathrm{N}_{2} \mathrm{O} \text { formation in fluidized beds; with C.J. } \\
\text { Tullin et al. 1993, Chalmers Univ. of Technology, } \\
\text { Göteborg, Sweden }\end{array}$ \\
\hline $\begin{array}{l}\text { D. Marlow } \\
\text { S. Niksa }\end{array}$ & $\begin{array}{l}\text { Stanford University, } \\
\text { Stanford, CA }\end{array}$ & combustion of soot from coal \\
\hline M. Nishioka & $\begin{array}{l}\text { BCR Nat. Lab., } \\
\text { Pittsburgh, PA }\end{array}$ & Coal structure (bituminous and lower rank) \\
\hline $\begin{array}{l}\text { J.O.L. Wendt } \\
\text { J.B. Mereb }\end{array}$ & $\begin{array}{l}\text { University of Arizona, } \\
\text { Tucson, AZ }\end{array}$ & $\begin{array}{l}\text { Reburning mechanisms for NOx abatement } \\
\text { (laboratory coal combustor) }\end{array}$ \\
\hline $\begin{array}{l}\text { D.S. Ross } \\
\text { B.H. Loo } \\
\end{array}$ & $\begin{array}{l}\text { SRI International, } \\
\text { Menlo Park, CA }\end{array}$ & Hydrothermal treatment of Wyodak coal \\
\hline J. Crelling & $\begin{array}{l}\text { Southern Illinois } \\
\text { University, Carbondale IL }\end{array}$ & $\begin{array}{l}\text { Release of nitrogen during combustion of coal chars } \\
\text { (experimental) }\end{array}$ \\
\hline $\begin{array}{l}\text { W.I. Friesen } \\
\text { O.I. Ogunsola } \\
\text { E. Furimsky }\end{array}$ & $\begin{array}{l}\text { CANMET, } \\
\text { Devon, Alberta, Canada }\end{array}$ & $\begin{array}{l}\text { Changes in low-rank coal pore structure and } \\
\text { component upgraded by heating in a nitrogen } \\
\text { atmosphere up to } 500^{\circ} \mathrm{C} \text {. another paper Furimski) of } \\
\text { effect of iron mixed with subbituminous coal on NOx } \\
\text { formation. }\end{array}$ \\
\hline $\begin{array}{l}\text { C.M.H. Brereton } \\
\text { C.J. Lim } \\
\text { J.R. Grace }\end{array}$ & $\begin{array}{l}\text { University of British } \\
\text { Columbia, } \\
\text { Vancouver, BC, Canada }\end{array}$ & $\begin{array}{l}\text { Pitch and coal combustion in circulating fluidized bed } \\
\text { combustors }\end{array}$ \\
\hline $\begin{array}{l}\text { A. Williams } \\
\text { H.K. Chagger } \\
\text { P.R. Goddard } \\
\text { V. Dupont } \\
\text { M. Pourkashanian } \\
\text { A.B. Fuertes }\end{array}$ & $\begin{array}{l}\text { University of Leeds, } \\
\text { Leeds, UK }\end{array}$ & $\begin{array}{l}\text { Modeling of NOx formation during pulverized coal } \\
\text { combustion; also interactions of } \mathrm{SO}_{2} \text { and NOx; two } \\
\text { papers by V. Dupont on NOx formation in natural } \\
\text { gas flames; paper by Fuertes on direct measurement } \\
\text { of coal ignition temperatures }\end{array}$ \\
\hline
\end{tabular}




\begin{tabular}{|c|c|c|}
\hline Researchers & Supporting Institution & Publications/Interests \\
\hline M.J. Richardson & $\begin{array}{l}\text { National Physics } \\
\text { Laboratory, } \\
\text { Teddington, UK } \\
\end{array}$ & Specific heats of coals, cokes, and ashes \\
\hline $\begin{array}{l}\text { K.M. Thomas } \\
\text { W.X. Wang } \\
\text { S.D. Brown } \\
\text { J.E. Varey } \\
\text { C.J. Hindmarsh } \\
\text { K. Grant } \\
\text { B.M. Gibbs }\end{array}$ & $\begin{array}{l}\text { University of Newcastle } \\
\text { upon Tyne and University } \\
\text { of London, UK. }\end{array}$ & $\begin{array}{l}\text { NO release and reactivity of coal chars; also } \mathrm{N}_{2} \mathrm{O} \\
\text { emissions from fluidized bed combustors; also } \\
\text { detection of intermediate compounds in combustion } \\
\text { and pyrolysis of coals }\end{array}$ \\
\hline $\begin{array}{l}\text { K.M. Laughlin } \\
\text { D.G. Gavin } \\
\text { G.P. Reed } \\
\text { M.A. Dorrington }\end{array}$ & $\begin{array}{l}\text { British Coal Corp., } \\
\text { Cheltenham, UK }\end{array}$ & $\begin{array}{l}\text { Nitrogen chemistry during pressurized fluidized bed } \\
\text { combustion of coal }\end{array}$ \\
\hline $\begin{array}{l}\text { C.F.M. Coumbra } \\
\text { I. Gulyurla } \\
\text { H. Esparteiro }\end{array}$ & $\begin{array}{l}\text { Instituto Superior Técnico, } \\
\text { Lisboa Codex, Portugal }\end{array}$ & $\begin{array}{l}\text { Mathematical model for predicting NOx emissions in } \\
\text { a } 300 \mathrm{MWe} \text { front wall fired pulverized coal } \\
\text { combustor; another paper on emissions from burning } \\
\text { waste oil; two papers on } \mathrm{NO} \text { and } \mathrm{N}_{2} \mathrm{O} \text { formation in } \\
\text { fluidized bed combustors }\end{array}$ \\
\hline $\begin{array}{l}\text { J.P. Hämäläinen } \\
\text { J.L. Tummavuori } \\
\text { M.J. Aho } \\
\text { Y. Lu } \\
\text { J. Saastamoinen } \\
\text { I. Hippinen }\end{array}$ & $\begin{array}{l}\text { Technical Research Center } \\
\text { of Finland, Jyväskylä, } \\
\text { Finland; also Espoo, } \\
\text { Finland }\end{array}$ & $\begin{array}{l}\text { Formation of } \mathrm{HCN} \text { and } \mathrm{NH}_{3} \text { from European coals and } \\
\text { peat; some papers consider effect of pressure; looked } \\
\text { at effect of coal composition; devolatilization and } \\
\text { char formation under pressurized fluidized bed } \\
\text { conditions; also } \mathrm{NOx} \text { and } \mathrm{N}_{2} \mathrm{O} \text { formation and control }\end{array}$ \\
\hline $\begin{array}{l}\text { J. Leppälahi } \\
\text { M.J. Aho } \\
\text { P.M. Pirkonen } \\
\end{array}$ & VIT Energy, Finland & $\begin{array}{l}\text { literature review on nitrogen emissions from } \\
\text { gasification of coal; also papers (Aho) on effect of } \\
\text { pressure }\end{array}$ \\
\hline $\begin{array}{l}\text { H. Miettinen } \\
\text { J.E. Johnsson } \\
\text { L.-E Åmand } \\
\text { A. Jensen } \\
\text { B. Leckner }\end{array}$ & $\begin{array}{l}\text { University of Göteborg or } \\
\text { Chalmers University of } \\
\text { Technology, Göteborg, } \\
\text { Sweden; Technical Univ. of } \\
\text { Denmark, Lyngby, } \\
\text { Denmark }\end{array}$ & $\begin{array}{l}\mathrm{N}_{2} \mathrm{O} \text { emissions in fluidized bed combustors; also NOx } \\
\text { formation in pressurized fluidized bed combustors }\end{array}$ \\
\hline $\begin{array}{l}\text { A. Nordin } \\
\text { L. Ericksson } \\
\text { M. Öhman } \\
\end{array}$ & $\begin{array}{l}\text { University of Umeå, Umeå, } \\
\text { Sweden }\end{array}$ & $\begin{array}{l}\text { NOx emissions and reduction in fluidized bed } \\
\text { combustors }\end{array}$ \\
\hline $\begin{array}{l}\text { M.A. Wójtowicz } \\
\text { J.R. Pels } \\
\text { J.A. Moulijn } \\
\text { W. Lin } \\
\text { J. Andries }\end{array}$ & $\begin{array}{l}\text { Delft Univ. of Technology, } \\
\text { Delft, The Netherlands }\end{array}$ & $\begin{array}{l}\text { Fate of coal nitrogen during pyrolysis and } \\
\text { combustion; also papers on } \mathrm{N}_{2} \mathrm{O} \text { emissions in } \\
\text { fluidized bed combustion; } \mathrm{Lin} \text { modeled } \mathrm{SO}_{2} \text { and } \mathrm{No}_{x} \\
\text { emissions in fluidized bed combustion }\end{array}$ \\
\hline $\begin{array}{l}\text { D.J. Morgan } \\
\text { J.P. Smart } \\
\text { M.A. Wójtowicz }\end{array}$ & $\begin{array}{l}\text { International Flame } \\
\text { Research Foundation, } \\
\text { The Netherlands }\end{array}$ & $\begin{array}{l}\text { Multifuel reburning for NOx reduction; another paper } \\
\text { on } \mathrm{N}_{2} \mathrm{O} \text { emission control in fluidized bed combustors }\end{array}$ \\
\hline
\end{tabular}




\begin{tabular}{|c|c|c|}
\hline Researchers & Supporting Institution & Publications/Interests \\
\hline $\begin{array}{l}\text { J.B. Illerup } \\
\text { K. Dam-Johansen }\end{array}$ & $\begin{array}{l}\text { Technical University of } \\
\text { Denmark, } \\
\text { Lyngby, Denmark }\end{array}$ & $\begin{array}{l}\text { Characterization of a full-scale pulverized coal boiler } \\
\text { (temperature, NOx ) }\end{array}$ \\
\hline $\begin{array}{l}\text { A. Kicherer } \\
\text { H. Spliethoff } \\
\text { H. Maier } \\
\text { K.R.G. Hein } \\
\text { U. Greul }\end{array}$ & $\begin{array}{l}\text { University of Stuttgart, } \\
\text { Stuttgart, Germany }\end{array}$ & $\begin{array}{l}\text { Air-staging and reburning to reduce NOx emissions } \\
\text { from pulverized coal combustors (experimental, } 0.5 \\
\text { MW test combustor) }\end{array}$ \\
\hline $\begin{array}{l}\text { B. Bonn } \\
\text { G. Pelz } \\
\text { H. Baumann }\end{array}$ & $\begin{array}{l}\text { DMT-Institute for } \\
\text { Cokemaking and Fuel } \\
\text { Technology, } \\
\text { Essen, Germany }\end{array}$ & $\mathrm{N}_{2} \mathrm{O}$ formation in fluidized bed boilers \\
\hline J.-R. Richard & $\begin{array}{l}\text { Laboratory de Combustion } \\
\text { et Systèmes Reactifs, } \\
\text { Orleans Cedex, France }\end{array}$ & Effect of pressure on NOx formation \\
\hline $\begin{array}{l}\text { P. Davini } \\
\text { P. Ghetti }\end{array}$ & Pisa University, Pisa, Italy & $\begin{array}{l}\text { Char surface area during combustion of pulverized } \\
\text { coal particles }\end{array}$ \\
\hline $\begin{array}{l}\text { M.J. Lázaro } \\
\text { J.V. Ibarra } \\
\text { L.F. de Diego }\end{array}$ & $\begin{array}{l}\text { Instituto de Carboquìmica, } \\
\text { Zaragozo, Spain }\end{array}$ & $\begin{array}{l}\text { Release of nitrogen during combustion of coal chars } \\
\text { in fluidized bed combustors }\end{array}$ \\
\hline $\begin{array}{l}\text { A. Karcz } \\
\text { S. Porada } \\
\text { J. Tomeczek } \\
\text { H. Palugniok }\end{array}$ & $\begin{array}{l}\text { Univ. of Mining and } \\
\text { Metallurgy, Kraków, } \\
\text { Poland; also Silesian Tech. } \\
\text { Univ., Katowice, Poland }\end{array}$ & $\begin{array}{l}\text { Pressure pyrolysis of coals; also properties of coal } \\
\text { undergoing pyrolysis }\end{array}$ \\
\hline $\begin{array}{l}\text { Y. Ohtsuka } \\
\text { H. Mori } \\
\text { K. Asami } \\
\text { H. Yamashita } \\
\text { A. Tomita } \\
\text { K. Nonaka } \\
\text { T. Watanabe } \\
\end{array}$ & $\begin{array}{l}\text { Tuhoku University, } \\
\text { Sendai, Japan }\end{array}$ & $\begin{array}{l}\text { Distribution of nitrogen species emitted during } \\
\text { pyrolysis of a subbituminous coal (effect of iron and } \\
\text { mineral matter); effect of addition of iron catalyst to } \\
\text { coal to improve } \mathrm{N}_{2} \text { and lower NO; also paper } \\
\text { (Yamashita et al 1993) on effect of char on reduction } \\
\text { of NO. }\end{array}$ \\
\hline $\begin{array}{l}\text { S. Kambara } \\
\text { T. Takarada } \\
\text { Y. Yamamoto } \\
\text { K. Kato } \\
\end{array}$ & $\begin{array}{l}\text { Idemitsu Kosan Co. Ltd, } \\
\text { Chiba, Japan; } \\
\text { Gumma University, } \\
\text { Gumma, Japan }\end{array}$ & $\begin{array}{l}\text { Relationship between coal-N and NOx emissions; } \\
\text { also (Kambara et al. 1995) relationship between } \\
\text { functional forms of coal-N and NOx precursors } \\
\text { during rapid pyrolysis }\end{array}$ \\
\hline $\begin{array}{l}\text { P.F. Nelson } \\
\text { M.D. Kelly }\end{array}$ & $\begin{array}{l}\text { CSIRO, } \\
\text { North Ryde, Australia }\end{array}$ & $\begin{array}{l}\text { Conversion of coal-N to NOx precursors under rapid } \\
\text { heating }\end{array}$ \\
\hline $\begin{array}{l}\text { J.O. Chae } \\
\text { Y.N. Chum }\end{array}$ & $\begin{array}{l}\text { Inha University, } \\
\text { Incheon, Korea }\end{array}$ & $\begin{array}{l}\text { NOx emissions, experimental two-stage combustor, } \\
\text { pulverized coal }\end{array}$ \\
\hline
\end{tabular}

Comments: (1) listings do not include work on catalytic reduction of NOx in the flue gas (e.g. by carbon, by injection of ammonia or urea, etc.), and (2) some papers on coal combustion or pyrolysis or drying, especially under pressure are included in this listing. 


\section{NOx LAWS AND REGULATIONS FOR COAL-FIRED ELECTRIC POWER PLANTS}

\section{Clean Air Act of 1990}

Two major sections of the Clean Air Act of 1990 affect maximum allowable NOx emission limits from coal-fired power plants. The first section is contained in Title I Part A, Air Quality and Emission Limitations, and Part D, Plan Requirements for Nonattainment Areas. The second is under Title IV, Acid Deposition Control. Title IV section 407 sets specific NOx limits from coal-fired boilers. Title I, Sections 107, 108, and 109 require the Environmental Protection Agency (EPA), referred to as the Administrator in the Clean Air Act, to set national ambient air quality standards and to review these standards every five years.

Areas of the country where ambient air quality standards are not met are called nonattainment areas for that pollutant. States must submit a plan to the EPA outlining how they will achieve attainment. Because large sources, such as utilities, are easier to target and control than many small sources, the result is that state or regional permitting agencies often set lower NOx emission limits than that specified under Title IV Section 407.

\section{Title IV, Acid Deposition Control, Section 407. Specific NOx Limits}

Section 407 of Title IV of the Clean Air Act establishes maximum allowable annual emissions for several classes of coal-fired boilers. There are two phases for compliance. Compliance for Phase I has been in effect since January 1, 1996. Compliance for phase II goes into effect January 1, 2000. Regulations are in 40 CFR Part 68. (See Table 4.)

Table 4. Phase I NOx Emission Limits Specified in the Clean Air Act

\begin{tabular}{|l|l|}
\hline Boiler Type & NOx Emissions, $\mathbf{b} / \mathrm{mmBtu}$ \\
\hline \hline Tangentially Fired & 0.45 \\
\hline $\begin{array}{l}\text { Dry Bottom Wall-fired } \\
\text { (except units applying cell burner technology) }\end{array}$ & 0.50 \\
\hline
\end{tabular}

The NOx emissions listed in Table 5 are given as calendar year averages. Also, quarterly reports must be sent to the U.S. EPA. States may adopt an "emissions cap and trade" program in which utilities may over-control at one plant to offset emissions at another plant, providing that overall NOx emissions are less than if each plant met the limits. 
Table 5. Phase II NOx Emission Limits

(Final Rule Published in Federal Register Dec. 19, 1996)

\begin{tabular}{|l|c|}
\hline Boiler Type & NOx Emissions, lb/mmBtu \\
\hline \hline Tangentially Fired & 0.40 \\
\hline $\begin{array}{l}\text { Dry Bottom Wall-fired } \\
\text { (except units applying cell burner technology) }\end{array}$ & 0.46 \\
\hline Wet-Bottom Wall-fired $>65 \mathrm{MW}$ & 0.84 \\
\hline Units Applying Cell Burner Technology & 0.68 \\
\hline Cyclone $>155 \mathrm{MW}$ & 0.86 \\
\hline Vertically Fired & 0.80 \\
\hline
\end{tabular}

\section{National Ambient Air Quality Standards}

The three pollutants that affect NOx emission limits set by regulatory agencies are NOx, ozone, and particulates. Current and proposed national standards for these pollutants are listed in Table 6. The Clean Air Act requires the EPA to review national ambient air quality standards every five years and set new standards based on health considerations.

Table 6. National Ambient Air Quality Standards for NOx, Ozone, and Particulates

\begin{tabular}{|l|l|l|}
\hline Pollutant & Current Standards & $\begin{array}{l}\text { New Standards Proposed Nov. 1996; } \\
\text { rules finalized July 1, 1997 }\end{array}$ \\
\hline \hline NOx (as equivalent $\mathrm{NO}_{2}$ ) & $0.053 \mathrm{ppm}$ & $0.053 \mathrm{ppm}$ \\
\hline ozone & $120 \mathrm{ppb}$ & $80 \mathrm{ppb}$ \\
\hline particulates & $\begin{array}{l}\text { annual average: } 50 \mu \mathrm{g} / \mathrm{m}^{3} \\
\text { daily maximum: } 150 \mu \mathrm{g} / \mathrm{m}^{3} \\
\text { particles regulated down to and } \\
\text { including 10 } \mu \mathrm{m}\end{array}$ & $\begin{array}{l}\text { annual average: } 15 \mu \mathrm{g} / \mathrm{m}^{3} \\
\text { daily maximum: } 50 \mu \mathrm{g} / \mathrm{m}^{3} \\
\text { particles regulated down to and } \\
\text { including } 2.5 \mu \mathrm{m}\end{array}$ \\
\hline
\end{tabular}

Plans for meeting the proposed new standards are due in 2002 for particulates and 2000 for ozone, with full compliance due several years later.

The country is now in compliance with NOx standards, but there are nonattainment areas for ozone and particulates. This will be especially true if the proposed standards take effect. Ozone is a component of smog produced when nitric oxides react with organic compounds in the air. The proposed $2.5 \mu \mathrm{m}$ size limit for particulates is in the range of nitric oxide condensation products (the brown haze around some cities from volatile organics, sulfur dioxide, and nitric oxides). Although coal-fired power plants probably contribute $20 \%$ (source: Nescaum, in Power Feb. 1994) to ambient NOx (compared with $45 \%$ from transportation sources and most of the remainder from agriculture fertilizers), it is easier for regulatory agencies to target a few large 
sources than many small sources. In a December 13, 1996, press release, the EPA estimates that electric utilities contribute approximately $33 \%$ of the NOx emissions.

Another part (Title I, Part D) of the Clean Air Act that affects limits on power plant NOx emissions is Section 169A on visibility protection for Federal Class I areas (for example, Grand Canyon National Park). This is also related to the brown haze problem. The result may be more stringent emission limits for some facilities than if they were located in other parts of the country.

\section{U.S. EPA Regulations (40 CFR Part 60.44)}

The EPA regulations establish NOx emission limits by coal type rather than by the type of boiler. (See Tables 7 and 8.) All NOx emission rates are expressed in terms of equivalent $\mathrm{NO}_{2}$ even though $\mathrm{NOx}$ is emitted typically as $\mathrm{NO}$ and sometimes as $\mathrm{N}_{2} \mathrm{O}$. State or regional permitting agencies may specify more stringent NOx limits than EPA regulations in order to meet ambient air quality standards in nonattainment areas. These are separate, stand-alone regulations from the Clean Air Act now in effect. The utility must meet whichever is most stringent.

If a mixture of coals or a mixture of coal and natural gas is used, the emission limit is prorated according to the heat value of the fuel. NOx emission limits for natural gas are either 0.10 or $0.20 \mathrm{lb} / \mathrm{mm}$ Btu, depending on the heating rate and size of the facility. Using natural gas as a reburning fuel in a coal-fired power plant is one of several methods available that effectively reduce NOx emissions. A utility employing this approach might derive $20 \%$ of the heating value from natural gas and $80 \%$ from coal, but the NOx reduction achieved may be more than offset by the more stringent EPA limit for coal alone.

Table 7. EPA NOx Emission Limits Specified in 40 CFR Part 60.44a for Utilities Combusting More Than 250 Million Btu/hr of Fossil Fuel

\begin{tabular}{|l|l|}
\hline Coal Fuel Type & NOx Emission Limits, lb/mm Btu \\
\hline \hline gaseous coal-derived fuel & 0.50 \\
\hline liquid coal-derived fuel & 0.50 \\
\hline solid coal, anthracite & 0.60 \\
\hline solid coal, bituminous & 0.60 \\
\hline solid coal, subbituminous & 0.50 \\
\hline $\begin{array}{l}\text { solid coal, more than 25\% lignite from North } \\
\text { Dakota; South Dakota, or Montana combusted } \\
\text { in a slag-type furnace }\end{array}$ & 0.80 \\
\hline $\begin{array}{l}\text { solid coal, more than 25\% lignite from North } \\
\text { Dakota, South Dakota, or Montana not } \\
\text { combusted in a slag-type furnace }\end{array}$ & 0.60 \\
\hline solid fuel derived from coal & 0.50 \\
\hline
\end{tabular}


Table 8. EPA NOx Emission Limits Specified in 40 CFR Part 60.44b for Utilities Combusting Between 100 and 250 Million Btu/hr of Fossil Fuel

\begin{tabular}{|l|l|}
\hline Coal or furnace type & NOx Emission Limits, $\mathrm{lb} / \mathrm{mm} \mathrm{Btu}$ \\
\hline \hline mass-feed stoker & 0.50 \\
\hline spreader stoker and fluidized bed combustion & 0.60 \\
\hline pulverized coal & 0.70 \\
\hline coal-derived synthetic fuels & 0.50 \\
\hline $\begin{array}{l}\text { lignite mined in North Dakota, South Dakota, } \\
\text { or Montana and combusted in a slag-type } \\
\text { furnace }\end{array}$ & 0.80 \\
\hline $\begin{array}{l}\text { other lignite or lignite not combusted in a slag- } \\
\text { type furnace }\end{array}$ & 0.60 \\
\hline
\end{tabular}

A fuel-neutral NOx emission limit of $0.15 \mathrm{lb} / \mathrm{mm}$ Btu under consideration by the EPA was shelved, at least for now. This limit would apply to utilities regardless of the kind of fuel. Critics pointed out that the limit was not fuel-neutral, as economics favored switching to natural gas. The limit could be met with coal only by applying very expensive technologies.

\section{Determination of NOx Emission Rates}

Nitrogen oxide emission rates are measured using a continuous monitoring system (40 CFR Part 60.47a; 40 CFR Part 60 Appendix F, procedure 1), which has been calibrated according to method 7 procedures specified under $40 \mathrm{CRF} 60$ Appendix A: Test Methods. At least two data points are required each hour from which a 1-hour average is calculated, and data must be taken for at least 18 hours/day and 22 days per 30-day month. The numbers are converted from parts per million (ppm) to $\mathrm{lb} / \mathrm{mm}$ Btu using procedures specified by Method 19 (also in 40 CFR Part 60, Appendix A). The utility then calculates a 30 -day rolling average according to procedures specified under 40 CFR Part $49 \mathrm{~b}$.

The calculation of NOx emission rates from ppm data first involves converting to pounds of NOx per standard cubic feet (lb/scf) and then converting scf to $10^{6} \mathrm{Btu}$ using an $\mathrm{F}$ factor. The procedures are specified by method 19 under 40 CFR Part 60 Appendix A. Method 19 allows the user to work in English or metric units, and calculate an F factor based on oxygen (dry basis), oxygen (wet basis), or carbon dioxide (dry or wet basis). For the purpose of illustration, the procedure for oxygen (dry basis) and in English units is described below.

1. The ppm NOx on a water-free basis is converted to lb/scf by multiplying by $1.194 \times 10^{-7}$ (dscf $=$ dry standard cubic feet). 
2. An $F$ factor is calculated (Method 19 calls the oxygen-dry basis $F$ factor $F_{d}$ ). The utility has the option of either using an $\mathrm{F}$ factor based on the type of coal burned or calculating an $\mathrm{F}$ factor from the coal ultimate analysis. (See Table 9.)

Table 9. F Factor for Converting dscf to $\mathrm{mm} \mathrm{Btu}$

\begin{tabular}{|l|l|}
\hline Coal & $\mathrm{F}_{\mathrm{d}}$ (units: dscf/10 $\mathrm{Btu}$ ) \\
\hline \hline Anthracite & 10,100 \\
\hline Bituminous & 9,780 \\
\hline Lignite & 9,860 \\
\hline $\begin{array}{l}\text { Based on } \\
\text { ultimate analysis }\end{array}$ & $\mathrm{F}_{\mathrm{d}}=10^{6}[3.64(\% \mathrm{H})+1.53(\% \mathrm{C})+0.57(\% \mathrm{~S})+0.14(\% \mathrm{~N})-0.46(\% \mathrm{O})] / \mathrm{G}$ \\
\hline
\end{tabular}

where $\mathrm{G}=$ gross caloric value of fuel, Btu/lb.

3. The emission rate is calculated

$$
\begin{aligned}
& \mathrm{E}=\mathrm{C}_{\mathrm{d}} \mathrm{F}_{\mathrm{d}}\left[20.9 /\left(20.9-\% \mathrm{O}_{2 \mathrm{~d}}\right)\right. \\
& \mathrm{E}=\text { NOx emission rate, } \mathrm{lb} / \mathrm{mm} \text { Btu } \\
& \mathrm{C}_{\mathrm{d}}=\text { NOx concentration, } \mathrm{lb} / \mathrm{dscf} \\
& \mathrm{F}_{\mathrm{d}}=\mathrm{F} \text { factor based on oxygen, dry basis } \\
& \% \mathrm{O}_{2 \mathrm{~d}}=\text { volume percent oxygen on a water-free basis }
\end{aligned}
$$

\section{POWER PLANT COMPLIANCE WITH NOX EMISSION LIMITS}

\section{General Comments}

In a Dec. 13,1996 , press release, EPA estimates that 85 to $90 \%$ of the coal-fired power plants can meet Clean Air Act Title IV Phase II NOx emission limits by employing a combination of low NOx burners and good computerized combustion control. Some utilities have reported improvement by switching to a different coal. If regulatory agencies impose more stringent standards, then additional technologies may need to be used, such as reburning using natural gas or other fuel, selective catalytic reduction (SCR) or selective noncatalytic reduction (SNCR) technologies. More stringent requirements are based on the Clean Air Act Title I compliance (ground-level ozone and smog air quality) rather than on Title IV compliance (specific NOx emission limitations). There is a lot of competition among equipment vendors offering technologies promising low NOx emissions, and some have complained (Leone 1994) that promises of low emissions have encouraged regulators to set even lower NOx emissions as a 
condition for power plants to obtain construction permits. This section reviews technologies used by new and existing power plants. Many plants use a combination of technologies.

\section{Keeping the Furnace Clean}

In a paper (Boocher 1995) presented at the 1995 International Joint Power Generation Conference, Joel Boocher of Diamond Power Specialty Co. said that NOx emissions may be reduced by as much as $40 \%$ by cleaning the furnace of slag deposits. The several power plants participating in the study showed between $15 \%$ and $40 \%$ NOx emission reduction after furnace cleaning with waterlances. Two of the plants used Powder River Basin coal. The slags produced from western coals were more tenacious and more resistant to wallblower cleaning than those of eastern coals. The furnaces were cleaned using a waterlance, which delivers high-pressure water through jets that travel along the tube wall. Heavy slag deposits in the furnace reduced local radiation heat transfer rates, and less heat transfer meant higher flue gas temperatures, as high as $3000^{\circ} \mathrm{F}\left(1650^{\circ} \mathrm{C}\right)$. The higher temperatures resulted in generation of significant thermal NOx.

Hill 1996 of Dairyland Power Cooperative Inc., La Crosse, Wisconsin, reported better control over NOx emissions by sootblowing in a 400-MW turbo-fired unit burning PRB coal with low-NOx burners. The NOx emissions were reduced from 0.6 to $0.3 \mathrm{lb} / \mathrm{mm} \mathrm{Btu}$ in a test before and after cleaning. Following the test, waterlances that operate based on a measurement of heat flux in various regions of the waterwalls were installed at the J.P. Madgett station; each lance operates for five minutes every five or six hours. This system has been in operation since 1992.

\section{Kind of Furnace}

While switching furnaces may not be an option for utilities, it should be mentioned that the kind of furnace affects NOx emissions and NOx reduction capability. Furnaces with generous dimensions are more capable of minimizing NOx formation and completing carbon dioxide burnout. Tight furnaces with high release rates are conducive to increased NOx emissions. Operating temperatures in tight furnaces are generally higher, which leads to the formation of thermal NOx. Wall- fired and tangentially fired units are more easily retrofitted with low-NOx burners than cyclone or turbo furnaces. Circulating fluidized bed boilers inherently operate at lower temperatures and have lower NOx emissions than pulverized coal boilers, but can emit some $\mathrm{N}_{2} \mathrm{O}$. Cell burners (manufactured in 1950s and 1960s) rapidly mix pulverized coal and combustion air resulting in highly turbulent and efficient combustion, but NOx emissions are high, typically 1.0 to $1.8 \mathrm{lb} / \mathrm{mm}$ Btu. 


\section{Coal Switching}

Much has been published (Makansi 1994a; Krameric and Rupinskas 1996; McComas and Morris 1995) on coal switching as a method of meeting Clean Air Act compliance for sulfur dioxide. Very little has been published on NOx. Many utilities have switched to low-sulfur, western subbituminous coal as a method of compliance. Alternatives such as full scrubbing have disadvantages, for example, scrubbing may rob the utility $8 \%$ of its power production and there are scrubber solids disposal costs. Switching from eastern to Powder River Basin (PRB) coal also involves major modifications in coal handling, coal preparation, to the furnace itself, and ash handling. Makansi 1994a has documented experiences of several utilities in switching to PRB coal.

Documentation on NOx is complicated by the fact that changes in coal also change combustion characteristics, and equipment must be optimized for burning that coal. There is mention of a reduction in NOx emissions from an unnamed facility (Makansi 1994b) with lowNOx burner technology installed when it switched from high-sulfur Illinois coal to PRB coal. When a utility switches from a high-sulfur coal to PRB coal, many other changes are made, so it is difficult to get a comparison based on the effect of a coal change only.

The University of North Dakota (Zygarlicke et al. 1995) compared the NOx levels in parts per million of four different coals combusted in a bench-scale drop tube furnace, first under normal conditions and then under lower temperatures and low excess air conditions. Every effort was made to control temperatures, oxygen concentrations, and retention times so that the conditions were the same. See Table 11.

Table 11. Comparison of NOx Emissions from Combusting Four Different Coals

\begin{tabular}{|l|l|l|}
\hline Coal & $\begin{array}{l}\text { Conventional Conditions }(21 \% \\
\left.\text { excess air, max temp } 1530^{\circ} \mathrm{C}\right)\end{array}$ & $\begin{array}{l}\text { Lower Temperature and } \\
\text { Excess Air Conditions }(3 \% \\
\text { excess air, max temp. 1430 }\end{array}$ \\
\hline Black Thunder Subbituminous & NOx $=359 \mathrm{ppm}$ & 166 \\
\hline Rochelle Subbituminous & 440 & 186 \\
\hline Illinois No. 6 Bituminous & 527 & 262 \\
\hline Beulah Lignite & 364 & 184 \\
\hline
\end{tabular}

\section{Tight Computerized Combustion Control}

Optimized combustion control is essential (Makansi 1996a) in any power plant program designed to reduce NOx emissions without loss in boiler performance. NOx emissions reduction 
is intimately tied to the complexities of combustion. Optimization includes use of computer software packages to precisely control stack oxygen readings ( $\approx 3 \%$ excess oxygen), air and fuel flows to each burner, stack emissions, and other parameters. An example is sequential process optimization, developed by Ultramax Corp., Cincinnati, Ohio, and enhanced by Electric Power Research Institute, which has been applied at a number of utilities (e.g. TVA, Georgia Power Co., Carolina Power and Light, Detroit Edison, nlinois Power Co., and Central \& Southwest Services Inc.).

Using the Ultramax software, the TVA New Johnsonville Plant reduced NOx emissions by 5 to $15 \%$, which was enough to enable it to comply with the Phase I Clean Air Act Title IV limit of $0.45 \mathrm{lb} / \mathrm{mm}$ Btu without special low-NOx burners. Under full-load optimization, the TVA units (T-fired) varied from 0.39 to $0.43 \mathrm{Btu} / \mathrm{mm}$ Btu. The Phase II limit, due in the year 2000 , is $0.40 \mathrm{lb} / \mathrm{mm}$ Btu. Another software package is called neural-network-based, closed-loop, supervisory control (Neusight), developed by Pegasus Technologies Corp., Painesville, Ohio. After testing the Neusight package at its New Castle Unit 5, Pennsylvania Power and Light reported a $25 \%$ reduction in NOx emissions, which was enough to enable it to meet limits set by state regulators without installing low-NOx burners (Makansi 1996a). Another system is EPRI's Gnocis, which is undergoing testing (in 1996) at Alabama Power Co.'s Gaston Unit 4. A software package developed jointly by Lockheed Martin Control Systems and New York State Electric and Gas Co. (called InEC) is undergoing testing at an 85-MW tangentially fired unit at the Goudey Station. It should be mentioned that I takes months to achieve these results, even after the necessary modifications are installed to optimize the boiler.

\section{Low-NOx Burners}

The use of low-NOx burners is closely tied with optimum combustion control. Storm 1993 has listed the following ten prerequisites for optimum combustion:

1. The furnace exit flue gas must be oxidizing ( $-3 \%$ excess oxygen).

2. Fuel fineness must be greater than $72 \%$ passing 200 mesh and less than $0.5 \%$ remaining on 50 mesh.

3. Fuel distribution must be within the range of $\pm 5 \%$ to $\pm 10 \%$ from burner to burner.

4. The primary air flow must follow a defined "ramp," usually with an air/fuel ratio of $1.8: 1$ at high pulverizer loads.

5. The primary air flows from each pulverizer must be measured and controlled for balance (within 10\%) compared with other pulverizers.

6. Secondary air flow to each group of burners must be proportional (within 10\%) to the fuel supplied to the individual burners.

7. Overfire air must be measured and controlled. 
8. Fuel flow to the pulverizers must be measured and controlled to the best tolerances available.

9. Pulverized-coal line velocities must remain above minimum velocity at low loads to minimize fuel settling and line plugging.

10. The fuel rate to the pulverizers must be constant with smooth flow rate changes during boiler load changes.

Low-NOx burners work on the dual principle that NOx emissions are reduced by depressing combustion-zone temperatures and by delaying the admission of sufficient oxygen to complete combustion in an internally staged burner with overfire air ports (OAP), or with fuel staging. The major problem with low-NOx burner retrofits is that they can easily leave unburned carbon in the ash. If unburned carbon remains in the ash, the power plant is not fully using the heat content of the fuel; also, the ash itself may be unsuitable for reuse applications, such as construction. To minimize unburned carbon, the burner equipment must be properly designed, and combustion control must be optimized. Examples of low-NOx burner retrofits are presented in Table 12.

Table 12. Low-NOx Burner Retrofit Coal-fired Utility Published Examples

\begin{tabular}{|c|c|c|c|c|c|}
\hline Utility & Unit & Coal & $\begin{array}{l}\text { Low NOx } \\
\text { Burner }\end{array}$ & $\begin{array}{l}\text { NOx Before } \\
\text { Retrofit, } \mathrm{lb} / \mathrm{mm} \\
\text { Btu, full load } \\
\end{array}$ & $\begin{array}{l}\text { NOx After Retrofit, } \\
\mathrm{lb} / \mathrm{mm} \text { Btu, full load }\end{array}$ \\
\hline $\begin{array}{l}\text { Black Hills } \\
\text { P\&L Co. }\end{array}$ & $\begin{array}{l}\text { 22-MW Simpson } \\
\text { Unit } 5 \text { (front wall } \\
\text { fired) }\end{array}$ & Wyodak coal & $\begin{array}{l}\text { B\&W DRB- } \\
\text { XCL with } \\
\text { OFA }\end{array}$ & 1.1 & $\begin{array}{l}0.37 \\
\text { (Makansi 1993) }\end{array}$ \\
\hline $\begin{array}{l}\text { Alabama } \\
\text { Power Co. }\end{array}$ & $\begin{array}{l}\text { 248-MW Gaston } \\
\text { Unit } 2 \text { (opposed } \\
\text { wall fired) }\end{array}$ & Pyxis coal & $\begin{array}{l}\text { B\&W DRB- } \\
\text { XCL with } \\
\text { OFA }\end{array}$ & 0.8 & $\begin{array}{l}0.4 \\
\text { (Makansi 1993) }\end{array}$ \\
\hline $\begin{array}{l}\text { Public Service } \\
\text { Co. of } \\
\text { Colorado }\end{array}$ & $\begin{array}{l}\text { 100-MW } \\
\text { Arapahoe Unit } 5 \\
\text { (roof fired) }\end{array}$ & $\begin{array}{l}\text { western } \\
\text { bituminous }\end{array}$ & $\begin{array}{l}\text { B\&W DRB- } \\
\text { XCL with } \\
\text { OFA }\end{array}$ & 1.15 & $\begin{array}{l}0.4 \\
\text { (Makansi 1993) }\end{array}$ \\
\hline $\begin{array}{l}\text { Dayton Power } \\
\text { \& Light Co. }\end{array}$ & $\begin{array}{l}\text { 605-MW Stewart } \\
\text { Unit } 4 \text { (opposed } \\
\text { wall fired) }\end{array}$ & $\begin{array}{l}\text { eastern } \\
\text { bituminous }\end{array}$ & $\begin{array}{l}\text { S-burners with } \\
\text { OFA ports }\end{array}$ & 1.17 & $\begin{array}{l}0.53 \\
\text { (Makansi 1993) }\end{array}$ \\
\hline $\begin{array}{l}\text { Ohio Edison } \\
\text { Co. }\end{array}$ & $\begin{array}{l}\text { Sammis Unit } 6 \\
\text { (cell burners) }\end{array}$ & $\begin{array}{l}\text { eastern } \\
\text { bituminous }\end{array}$ & $\begin{array}{l}\text { B\&W DRB- } \\
\text { XCL with } \\
\text { OFA }\end{array}$ & 1.35 & $\begin{array}{l}0.4 \\
\text { (Makansi 1993) }\end{array}$ \\
\hline $\begin{array}{l}\text { Southern Calif. } \\
\text { Edison Co. }\end{array}$ & $\begin{array}{l}\text { 215-MW } \\
\text { Mandalay Unit } 1\end{array}$ & $\begin{array}{l}\text { natural gas or } \\
\text { oil }\end{array}$ & $\begin{array}{l}\text { S-burners with } \\
\text { OFA ports }\end{array}$ & $\begin{array}{l}\text { Gas: } 0.18(150 \\
\text { ppm); oil } 0.22 \\
(180 \text { ppm })\end{array}$ & $\begin{array}{l}\text { Gas: } 0.03(25 \mathrm{ppm}) \\
\text { oil } 0.13(105 \mathrm{ppm}) \\
\text { (Makansi 1993) }\end{array}$ \\
\hline $\begin{array}{l}\text { Wisconsin } \\
\text { P\&L Co. }\end{array}$ & $\begin{array}{l}310 \text { MW Oak } \\
\text { Creek Unit } 7\end{array}$ & no inform. & $\begin{array}{l}\text { Foster Wheeler } \\
\text { Tangential } \\
\text { Low-NOx with } \\
\text { fuel staging }\end{array}$ & 0.68 & $\begin{array}{l}0.35 \\
\text { (Morris and } \\
\text { Sweeney 1995) }\end{array}$ \\
\hline $\begin{array}{l}\text { Wisconsin } \\
\text { P\&L Co. }\end{array}$ & $\begin{array}{l}\text { 100-MW Dewey } \\
\text { Unit 2, Cyclone }\end{array}$ & $\begin{array}{l}\text { eastern } \\
\text { bituminous }\end{array}$ & $\begin{array}{l}\text { S-burners with } \\
\text { fuel staging }\end{array}$ & 0.83 & $\begin{array}{l}0.38 \\
\text { (Makansi 1993) }\end{array}$ \\
\hline
\end{tabular}




\begin{tabular}{|c|c|c|c|c|c|}
\hline Utility & Unit & Coal & $\begin{array}{l}\text { Low NOx } \\
\text { Burner }\end{array}$ & $\begin{array}{l}\text { NOx Before } \\
\text { Retrofit, lb/mm } \\
\text { Btu, full load }\end{array}$ & $\begin{array}{l}\text { NOx After Retrofit, } \\
\mathrm{lb} / \mathrm{mm} \text { Btu, full load }\end{array}$ \\
\hline $\begin{array}{l}\text { American } \\
\text { Power Co. }\end{array}$ & $\begin{array}{l}600-\mathrm{MW} \\
\text { Muskingum River } \\
\text { Unit } 5 \text { Cell } \\
\text { Burner }\end{array}$ & $\begin{array}{l}\text { eastern } \\
\text { bituminous? }\end{array}$ & $\begin{array}{l}\text { Riley Stoker } \\
\text { CCV }\end{array}$ & $1.2(1.0$ to 1.8$)$ & $\begin{array}{l}0.51 \\
\text { (see Penterson and } \\
\text { Dorai 1995) }\end{array}$ \\
\hline $\begin{array}{l}\text { Georgia Power } \\
\text { Co. }\end{array}$ & $\begin{array}{l}\text { Yates Plant, } \\
\text { several T-fired } \\
\text { units }\end{array}$ & $\begin{array}{l}\text { eastern } \\
\text { bituminous? }\end{array}$ & $\begin{array}{l}\text { ICL flame } \\
\text { attached } \\
\text { nozzle; Yates } \\
\text { Units } 6 \& 7 \\
\text { with SOFA }\end{array}$ & $\begin{array}{l}\text { Reductions of } \\
\text { NOx of } 40 \% \\
\text { typical; see } \\
\text { Jones } 1995\end{array}$ & $\begin{array}{l}\text { vendor guarantee } \\
\text { meets } 0.4 \mathrm{lb} / \mathrm{mm} \\
\text { Btu limit }\end{array}$ \\
\hline $\begin{array}{l}\text { Georgia Power } \\
\text { Co. }\end{array}$ & $\begin{array}{l}\text { Bowen Plant, } \\
\text { several T-fired } \\
\text { units }\end{array}$ & $\begin{array}{l}\text { eastern } \\
\text { bituminous? }\end{array}$ & $\begin{array}{l}\text { ICL flame } \\
\text { attached nozzle } \\
\text { with SOFA }\end{array}$ & see Jones 1995 a & $\begin{array}{l}\text { vendor guarantee } \\
\text { meets } 0.4 \mathrm{lb} / \mathrm{mm} \\
\text { Btu limit }\end{array}$ \\
\hline $\begin{array}{l}\text { United } \\
\text { Illuminating } \\
\text { Co. }\end{array}$ & $\begin{array}{l}\text { 390-MW } \\
\text { Bridgeport Harbor } \\
\text { Unit } 3 \\
\text { (T-fired) }\end{array}$ & $\begin{array}{l}\text { Kentucky low- } \\
\text { sulfur coal }\end{array}$ & $\begin{array}{l}\text { ABB-CE } \\
\text { Services } \\
\text { TFS2000 }{ }^{\text {tm }} \mathrm{R} \\
\text { burner with } \\
\text { OFA }\end{array}$ & 0.55 to 0.66 & $\begin{array}{l}\text { exceeds } 0.38 \mathrm{lb} / \mathrm{mm} \\
\text { Btu Connecticut } \\
\text { limit (ozone non- } \\
\text { attainment area); } \\
\text { see Jones } 1995 \mathrm{~b}\end{array}$ \\
\hline $\begin{array}{l}\text { Kentucky } \\
\text { Utilities }\end{array}$ & $\begin{array}{l}517 \text { MW Ghent } \\
\text { Unit } 1 \text { (T-fired) }\end{array}$ & $\begin{array}{l}\text { Kentucky } \\
\text { bituminous } \\
11400 \mathrm{Btu} / \mathrm{lb} \\
\end{array}$ & $\begin{array}{l}\text { ABB-CE } \\
\text { concentric with } \\
\text { SOFA }\end{array}$ & $\begin{array}{l}0.539(0.471 \\
\text { combustion } \\
\text { control only) }\end{array}$ & $\begin{array}{l}0.37 \\
\text { (Gabrielson et al. } \\
\text { 1995) }\end{array}$ \\
\hline $\begin{array}{l}\text { Housier } \\
\text { Energy }\end{array}$ & $\begin{array}{l}\text { each 116.6 MW } \\
\text { Frank E. Ratts } \\
\text { Units 1 \& } 2 \\
\end{array}$ & $\begin{array}{l}\text { not specified } \\
\text { except low } \\
\text { sulfur }\end{array}$ & $\begin{array}{l}\text { Foster Wheeler } \\
\text { with fuel } \\
\text { staging } \\
\end{array}$ & $\begin{array}{l}1.1 \\
\text { (Reynolds et } \\
\text { al. 1995) } \\
\end{array}$ & $\begin{array}{l}\text { Unit 1: } 0.48 \\
\text { Unit 2: } 0.46\end{array}$ \\
\hline $\begin{array}{l}\text { Duquesne } \\
\text { Light Co. }\end{array}$ & $\begin{array}{l}\text { Elrama Power } \\
\text { Stat., Units } 1 \& 2 \\
\text { each } 110 \mathrm{MW}, \\
\text { Unit } 3120 \mathrm{MW} \\
\end{array}$ & $\begin{array}{l}\text { high volatile } \\
\text { bituminous }\end{array}$ & $\begin{array}{l}\text { Energy } \\
\text { Systems Assoc. } \\
\text { (Pittsburgh) } \\
\text { with SOFA }\end{array}$ & $\begin{array}{l}0.8 \text { (all units) } \\
\text { (Bionda et al. } \\
\text { 1995) }\end{array}$ & $\begin{array}{ll}\text { Unit 1: } & 0.44 \\
\text { Unit 2: } & 0.43 \\
\text { Unit 3: } & 0.42\end{array}$ \\
\hline $\begin{array}{l}\text { Owensboro } \\
\text { Municipal } \\
\text { Utility }\end{array}$ & $\begin{array}{l}\text { Elmer Smith } \\
\text { Station, 151 MW } \\
\text { Unit 1 (cyclone); } \\
265 \text { MW Unit } 2 \\
\text { (T-fired) }\end{array}$ & $\begin{array}{l}\text { Western } \\
\text { Kentucky (3\% } \\
\mathrm{S}, 1.55 \% \mathrm{~N}, \\
11,000 \mathrm{Btu} / \mathrm{lb})\end{array}$ & $\begin{array}{l}\text { International } \\
\text { Combustion } \\
\text { Concentric } \\
\text { Firing with } \\
\text { close coupled } \\
\text { OFA and flame } \\
\text { attached nozzle }\end{array}$ & $\begin{array}{l}\text { Unit 2: 0.6 } \\
\text { (Conn et al. } \\
\text { 1995) }\end{array}$ & Unit 2: 0.37 \\
\hline $\begin{array}{l}\text { PECO Energy } \\
\text { Co. }\end{array}$ & $\begin{array}{l}160 \text { MW Cromby } \\
\text { Unit } 1\end{array}$ & $\begin{array}{l}\text { Eastern } \\
\text { bituminous }\end{array}$ & $\begin{array}{l}\text { B\&W PRB- } \\
\text { XCL with } \\
\text { OFA }\end{array}$ & $\begin{array}{l}0.61 \text { to } 1.0 \\
\text { (Trego et al. } \\
1995 \text { ); }\end{array}$ & $\begin{array}{l}0.44 \text { (can get } 0.34 \\
\text { with flyash carbon } \\
\text { of } 11.3 \% \text { ); } \\
\text { regulatory limit } \\
0.35\end{array}$ \\
\hline $\begin{array}{l}\text { American } \\
\text { Electric Power } \\
\text { Service Co. }\end{array}$ & $\begin{array}{l}240 \text { MW Glen } \\
\text { Lyn Unit 6; } 165 \\
\text { MW Conesville } \\
\text { Unit } 3 \text { (both front } \\
\text { wall fired) }\end{array}$ & $\begin{array}{l}\text { Glen Lyn: SW } \\
\text { Virginia; } \\
\text { Conesville: } \\
\text { Ohio coals }\end{array}$ & $\begin{array}{l}\text { DB Riley Inc. } \\
\text { CCV Burners } \\
\text { (venturi) } \\
\text { without OFA. }\end{array}$ & $\begin{array}{l}\text { Glen Lyn: } \\
0.50 \text { to } 0.53 \\
\text { Conesville: } 1.1\end{array}$ & $\begin{array}{l}\text { Glen Lyn: } \\
0.48 \text { to } 0.53 \\
\text { Conesville: } \\
0.48 \text { to } 0.53 \\
\text { (Penterson and } \\
\text { Dorman } 1995 \text { ) } \\
\end{array}$ \\
\hline
\end{tabular}

Comments on burners: S-burner is a sliding damper burner with air measurement features; DRB-XCL is a dualregister burner with sliding damper of S-burner type marketed by Babcock \& Wilcox; OFA means overfire air ports; fuel staging means that the fuel is split into two streams, each burning with a different stoichiometry; Riley Stoker Co. CCV burner is a controlled combustion venturi retrofit that uses neither OFA nor fuel staging; ICL (International Combustion Co. of Atlanta, GA) has also developed a low NOx burner with an option of separated overfire air (SOFA); the ABB C-E Services, Inc., Windsor, Conn. burner is described by Jones $1995 \mathrm{~b}$. 
Several authors (Jones 1995b; Storm 1993) have emphasized that utilities cannot simply install low-NOx burners in an existing boiler and expect to see major reductions in NOx emissions. Experience demonstrates that burner retrofits require more precise combustion and fuel flow management than the original designs.

Foster Wheeler has summarized its field experience (Steitz and Cole 1996) with low-NOx burners in wall fired installations. The design of low-Nox burners is critical; the authors remark that even very minor changes in the discharge configuration of the nozzle design has resulted in NOx reductions on the order of 25-30\%. Additional field experience with other low-NOx burners is summarized by Thompson et al. 1996.

Power magazine (a McGraw Hill publication) maintains a web site at where utilities can communicate their experience using low NOx burners (http.//www.powermag.com; click under "LNB Challenge"). Some of this information is summarized in the public domain (Jones 1997). The two main problems that have surfaced using low-NOx burners are (1) excessive waterwall tube wastage and (2) increased carbon and fly ash. Both problems are related with the need to have a fuel-rich reducing atmosphere to convert fuel nitrogen to $\mathrm{N}_{2}$ rather than NO. In an oxidizing atmosphere, protective scales are formed on the water tubes, which resist further corrosion. In a reducing atmosphere, sulfides and not oxides are formed; the sulfides form iron sulfides with the water tube surfaces. The result is excessive tube corrosion. Additionally, not all the fuel is burned in a reducing atmosphere, resulting in excessive carbon in the flyash. Unburned carbon in the flyash represents loss in heating value of the fuel and creates a flyash disposal problem. Load cycling exacerbates the problem because it changes the flue-gas composition and the oxidizing/reducing characteristics.

The problem is trying to maintain a tight balance between the need to have a fuel-rich reducing atmosphere for minimum NO formation but also have an oxidizing atmosphere to minimize tube wastage and unburned carbon in the flyash. Tight, computerized control of the fuel/air characteristics helps achieve the right balance, but judging from utility response (Jones 1997) it is not an easy thing to accomplish. For example, in a test (Trego et al. 1995) with a wallfired unit, PECO could achieve $0.44 \mathrm{lb}$ NOx/mm Btu at $3 \%$ carbon in their flyash (B\&W DRBLCL low-NOx burner) and $0.34 \mathrm{lb} / \mathrm{mm}$ Btu at $11.3 \%$ carbon in their flyash.

According to Pepco (Potomac Electric Power Co., Washington, D.C., cited by Jones 1997), the burning of coals containing more than $1.5 \%$ sulfur in low-NOx burners particularly results in excessive water tube corrosion. To minimize corrosion, Pepco is experimenting with chromized replacement panels and high-alloy weld overlays. Other utilities (e.g. Cinergy, Cincinnati, Ohio, also cited by Jones 1997) are also experimenting with tube chromizing and weld overlays and also diverting combustion air to the tube regions to help maintain oxidizing conditions. New York State Electric \& Gas Co. (Bingham, NY) also has gone to the expense of 
upgrading pulverizers to improve coal fineness by $30 \%$ and has further upgraded their low-NOx burners to a concentric firing system with SOFA. Better coal fineness improves char combustion and reduces the carbon content of water tube deposits (and therefore resulting in less sulfide corrosion). A lot more is involved than the expense of installing low-NOx burners and computerized combustion control. Utilities have challenged the U.S. EPA on the EPA-estimated costs (e.g. \$270/ton for wall-fired units and $\$ 611 /$ ton for tangentially fired units for phase I) for NOx controls.

The use of Powder River Basin coals may offer the benefit of reduced NOx emissions compared with burning eastern coals when using low-NOx burners. According to George Offen 1997, Electric Power Research Institute (EPRI) program manager for NOx emissions, utilities have reported a 20 to $30 \%$ decrease in NOx emissions compared with burning eastern coals, but the data are proprietary and cannot be released to non-EPRI members. The limited information in the public domain (Power magazine, the Internet, and Makansi 1993) indicates numbers of around $0.3 \mathrm{Btu} / \mathrm{mm}$ Btu (Dairyland Power Cooperative Inc.) or $0.38 \mathrm{lb} / \mathrm{mm}$ Btu (Black Hills Power and Light) with PRB coals and tangentially fired boilers compared with often higher numbers for eastern coals (Table 12). The EPA limit (phase II controls) is $0.4 \mathrm{lb} / \mathrm{mm}$ Btu.

From a coal analysis of nitrogen functional forms, the formulations presented in Kambara et al. 1995 show that burning Wyoming subbituminous coal with low-NOx burners should result in lower NOx emissions than burning eastern coals with low-NOx burners. However, it is necessary to keep the furnace clean using waterlances to remove any slag buildup, otherwise NOx concentrations will increase (Hill 1996). The lower sulfur content of PRB coals should also be beneficial in reducing water tube corrosion. The experiences of three utilities in switching from high-sulfur eastern coal to PRB coal are documented by Krameric and Rupinskas 1995 and McComas and Morris 1995.

\section{Natural Gas Co-Firing and Reburning}

Natural gas co-firing is the combustion of natural gas with coal in the primary combustion zone of coal-fired boilers. In most co-firing applications, the natural gas contribution is limited to about $20 \%$ of the thermal input. The gas may be supplied by ignitors, warmup guns, or gas burners. Benefits are (1) increased capacity, (2) improved precipitator performance, (3) enhanced coal-switching capability, (4) reduced boiler startup and warmup times, and (5) reduced $\mathrm{SO}_{2}$ and NOx emissions.

Reburning is a co-firing technology specifically directed towards reducing NOx emissions. In gas reburning, natural gas is injected into the boiler above the main heat-release zone to convert nitric oxide (NO) to molecular nitrogen. According to Swanekamp 1996, maximum NO 
reduction is achieved when sufficient gas is added to create sub-stoichiometric conditions in the reburn zone; following the reburn zone, overfire air must be added to complete the process. Natural gas provides 15 to $20 \%$ of the heat input. Overall NOx emissions are reduced by 50 to $75 \%$, as shown in Table 13.

\section{Selective Catalytic Reduction (SCR)}

Ammonia is added to the flue gas to reduce NOx to water and elemental nitrogen. The reaction normally proceeds at temperatures between $1600^{\circ} \mathrm{F}$ and $2200^{\circ} \mathrm{F}\left(871^{\circ} \mathrm{C}\right.$ and $\left.1204^{\circ} \mathrm{C}\right)$, but a catalyst is used to promote the reaction at a lower temperature. The technology can be used to achieve $90 \%$ and greater NOx reduction in oil-fired or gas-fired units, which have a more confined heat release zone compared with coal-fired units. Still, up to about $70 \%$ NOx additional removal has been achieved with coal-fired systems. An example is the 285-MW Chamber Works plant in Carney's Point, N.J., with an inlet NOx flue gas concentration of $196 \mathrm{ppm}$, outlet NOx of $73 \mathrm{ppm}$, catalyst temperature in the range of 570 to $750^{\circ} \mathrm{F}$, and ammonia slip of $5 \mathrm{ppm}$. With gas turbine systems, NOx emissions below $10 \mathrm{ppm}$ (even below $7 \mathrm{ppm}$ ) are possible with SCR units.

Table 13. Published Examples of Gas Reburning

\begin{tabular}{|l|l|l|l|l|}
\hline Utility & Unit & Coal & $\begin{array}{l}\text { Baseline NOx } \\
\text { lb/mm Btu, } \\
\text { full load }\end{array}$ & $\begin{array}{l}\text { NOx With } \\
\text { Reburning, lb/mm } \\
\text { Btu, full load }\end{array}$ \\
\hline $\begin{array}{l}\text { Illinois } \\
\text { Power }\end{array}$ & $\begin{array}{l}\text { 71 MW Hennepin } \\
\text { Unit 1 } \\
\text { T-fired }\end{array}$ & $\begin{array}{l}\text { high sulfur } \\
\text { Illinois coal }\end{array}$ & 0.75 & 0.245 \\
\hline $\begin{array}{l}\text { City Water } \\
\text { Light \& } \\
\text { Power }\end{array}$ & $\begin{array}{l}\text { 30 MW Lakeside } \\
\text { Unit 7, Cyclone }\end{array}$ & $\begin{array}{l}\text { not } \\
\text { specified }\end{array}$ & 0.95 & 0.344 \\
\hline $\begin{array}{l}\text { Public } \\
\text { Service Co. } \\
\text { of Colorado }\end{array}$ & $\begin{array}{l}\text { Cherokee Unit 3, } \\
\text { wall-fired }\end{array}$ & $\begin{array}{l}\text { Colorado } \\
\text { low sulfur } \\
\text { bituminous }\end{array}$ & $\begin{array}{l}0.73 \text { baseline } \\
0.48 \text { with } \\
\text { Foster Wheeler } \\
\text { Low-NOx fuel } \\
\text { staging }\end{array}$ & $\begin{array}{l}0.26 \text { (both gas } \\
\text { reburning and low- } \\
\text { NOx burner) }\end{array}$ \\
\hline
\end{tabular}

From Folsom et al. 1996.

In a coal-fired unit, the SCR unit may be placed either between the economizer and air heater, between the particulate collection device and a flue-gas desulfurization unit, or after the flue-gas desulfurization unit. In a gas-turbine application, the SCR unit is typically placed within the heat recovery steam generator.

Several classes of catalysts may be used. One class is primarily aluminum oxide. Another formulation includes vanadium pentoxide (the active ingredient) and titanium dioxide or aluminum 
oxide (a carrier) with tungsten trioxide (reduces unwanted $\mathrm{SO}_{2}$ oxidation to $\mathrm{SO}_{3}$ ). Two other classes of catalysts are based on iron oxide or activated carbon. One problem is the oxidation of sulfur dioxide to sulfur trioxide, which reacts with ammonia to form sticky ammonia salts. The salts blind catalyst surfaces and can also induce acid corrosion downstream. Other factors that reduce catalyst life are arsenic and lead from coal combustion. The size of the SCR unit and the amount of catalyst depend on the pitch (spacing from centers of adjacent openings). A smaller pitch means greater surface area within a confined flue duct space but greater potential for plugging. Another downside of a catalyst is it contributes to the pressure drop in the flue gas, which in turn results in increased fan power consumption.

Ammonia may be added as anhydrous or aqueous ammonia. The amount added is crucial. If too much is added, flyash may be contaminated with ammonium salts, making disposal or flyash reuse is impossible. The ammonia slip should be as low as possible ( 3 to $5 \mathrm{ppm}$ ).

The Southern Electric International 245-MW Birchwood Station (in Virginia) is in an ozone nonattainment area and is permitted at $0.15 \mathrm{lb} \mathrm{NOx} / \mathrm{mm}$ Btu. To achieve this low emission level, the facility uses a combination of good combustion control, low-NOx burners (ABB-CE Services TFS $2000^{\mathrm{TM}}$ ), and downstream SCR. ABB Combustion Engineering, Inc. is guaranteeing $0.1 \mathrm{lb} / \mathrm{mm}$ Btu after SCR, according to Makansi 1996b.

Another system (Cho and Snapp 1994) has been tested at the Keystone Cogeneration Plant in Logan Township, NJ, also in an ozone nonattainment area. The 230-MW Unit uses eastern bituminous coal with a heat content of $13054 \mathrm{Btu} / \mathrm{lb}$ (HHV). The Low-NOx burners (Foster Wheeler, internally fuel staged with overfire air) result in a furnace NOx emission of 0.27 $\mathrm{lb} / \mathrm{mm}$ Btu. Injection of $27 \%$ aqueous ammonia and use of a plate catalyst (mfg. Siemens AG, Germany) reduces NOx emissions to $0.10 \mathrm{lb} / \mathrm{mm}$ Btu.

\section{Selective Non-Catalytic Reduction (SNCR)}

Anhydrous ammonia, aqueous ammonia, or urea is added to the furnace where temperatures are in the range of 1600 to $2000^{\circ} \mathrm{F}\left(871\right.$ to $\left.1093^{\circ} \mathrm{C}\right)$. Urea dissociates to ammonia in the furnace. At temperatures above $2000^{\circ} \mathrm{F}\left(1093^{\circ} \mathrm{C}\right)$, additional NOx can form. At temperatures below $1600^{\circ} \mathrm{F}\left(871^{\circ} \mathrm{C}\right)$, the ammonia slip can be too high. Sometimes additives such as oxygenated hydrocarbons are blended with the ammonia or urea formulation to extend the temperature window. The formulation is injected at multiple ports to ensure uniform distribution in the flue gas and at the proper temperature window. 
Sometimes both SNCR and SCR technologies are used, with the formulation injected at multiple ports, including the furnace, and a catalyst in the flue gas ductwork. Also, a stand-alone SNCR may be installed and a catalyst structure added later as a polishing step.

\section{CONCLUSIONS}

- The NOx emissions that occur as a result of coal combustion depend primarily on how the coal is burned and only to a minor extent on properties of the coal itself. The NOx emissions may be classified into (1) thermal NOx , (2) prompt NOx, and (3) NOx originating from fuel nitrogen. The NOx originating from coal nitrogen may be subdivided into (1) homogeneous reactions producing $\mathrm{NOx}$ from $\mathrm{HCN}$ and $\mathrm{NH}_{3}$ intermediates from coal volatiles and (2) heterogeneous reactions taking place on the coal char surface from char nitrogen. The combination of tight combustion control and use of low-NOx burners at coal-fired utilities has been demonstrated as being successful in controlling thermal, prompt, and coal volatile (homogeneous phase) NOx; the technologies are less successful in controlling NOx from char nitrogen.

- In a December 1996 press release, the EPA estimated that 85 to $90 \%$ of the utilities can meet the Clean Air Act Phase II limitations on NOx (e.g. $0.4 \mathrm{lb} \mathrm{NOx} / \mathrm{mm}$ Btu for tangentially fired boilers, other limits for other boiler configurations) under Title IV, Acid Deposition Control, using low-NOx burners and tight combustion control. Available published data from utilities show that this limit is near the edge of what is possible, practically speaking, and that many utilities have experienced increased carbon in the flyash and increased fireside tube corrosion.

- Coal properties that affect NOx emissions include nitrogen content of the coal, coal reactivity, and mineral makeup of the coal. While coal properties only affect NOx emissions in a minor way compared to how the coal is burned, because the EPA emission limits are near the ragged edge of what tight combustion control and low-NOx burners are capable of, any benefit will help.

- Based on (1) the relative proportions of quaternary, pyrolic, and pyridinic nitrogen functionality groups in the coal, and (2) the coal nitrogen, Powder River Basin coal is predicted to result in roughly $20 \%$ less NOx emission than many eastern U.S. coals when burned in utility boilers employing tight combustion control and low-NOx burners. Unpublished utility data from the Electric Power Research Institute also show roughly $20 \%$ less NOx emission when switching to PRB coal.

- One warning is that utilities burning PRB coal can experience increased slag buildup, higher temperatures, and as a result, higher NOx emissions. Frequent cleaning (e.g use of waterlances at some utilities) is required for those situations. 


\section{REFERENCES}

Aho, M.J., J.P. Hämäläinen, and J.L. Tummavuori. 1993. Conversion of Peat and Coal Nitrogen through $\mathrm{HCN}$ and $\mathrm{NH}_{3}$ to Nitrogen Oxides at $800^{\circ} \mathrm{C}$. Fuel 72(6). pp. 837-841.

Åmand, L.-E. and B. Leckner. 1993. Formation of $\mathrm{N}_{2} \mathrm{O}$ in a Circulating Fluidized Bed Combustor. Energy and Fuels 7(6) pp. 1097-1107.

Bassilakis, R., Y. Zhao, P. Solomon, and M.A. Serio. 1993. Sulfur and Nitrogen Evolution in Argonne Coals: Experiment and Modeling. Energy and Fuels. 7(6) pp. 710-720.

Bionda, J.P. , R.W. Glickert, A. Hallo, and G.F. Gretz. 1995. Development of a Low-NOx Combustion System for a Roof-Fired Utility Boiler. Proceedings of the 1995 International Joint Power Generation Conference. American Society of Mechanical Engineers, Minneapolis, MN. pp. 81-88.

Boocher, J. 1995. NOx Reduction through Furnace Cleaning: Empirical Evidence. Proceedings of the 1995 International Joint Power Generation Conference. American Society of Mechanical Engineers, Minneapolis, MN. pp. 313-315.

Cai, H.-Y., A.J. Güell, D.R. Dugwell, and R. Kandiyoti. 1993. Heteroatom Distribution in Pyrolysis Products as a Function of Heating Rate and Pressure. Fuel 72(3). pp. 321-327.

Cai, H.-Y., A.J. Güell, I.N. Chatzakis, J.-Y. Lim, D.R. Dugwell, and R. Kandiyoti. 1996. Combustion Reactivity and Morphological Change in Coal Chars: Effect of Pyrolysis Temperature, Heating Rate and Pressure. Fuel 75(1) pp. 15-24.

Chae, J.O. and Y.N. Chun. 1991. Effect of Two-stage Combustion on NOx Emissions in Pulverized Coal Combustion. Fuel 70 (June 1991) pp. 703-707.

Chen, W., L.D. Smoot, T.H. Fletcher, and R.D. Boardman. 1996. Part 1: A Computational Method for Determining Global Fuel-NO Rate Expressions. Part 2: Global Rate Expression for Nitric Oxide Reburning. Energy and Fuels 10(5). pp. 1036-1045 (part 1) and 1046-1052 (part 2).

Cho, S.M. and R.B. Snapp. 1994. Design of a Selective Catalytic Reduction System for NOx Emission Control in the Keystone Generation Plant. Proceedings of the American Power Conference, 56-II, Chicago, IL. pp. 1279-1284.

Colannino, J. 1993. Low-cost Techniques Reduce Boiler NOx. Chemical Engineering 100(2) February 1993. McGraw Hill. pp. 100-106.

Collings. M.E., M.D. Mann, and B.C. Young. 1993. Effect of Coal Rank and Circulating Fluidized-Bed Operating Parameters on Nitrous Oxide Emissions. Energy and Fuels 7(4) pp. 554-558. 
Conn, S.K., R.A. Band, A.W. Thompson, J.W. Allen. Influence of Coal Properties on NOx Emissions. Proceedings of the 1995 International Joint Power Generation Conference. American Society of Mechanical Engineers, Minneapolis, MN. pp. 293-303.

Dupont, V., M. Pourkashanian, A. Williams, and R. Wooley. 1993. The Reduction of NOx Formation in Natural Gas Burner Flames. Fuel 72(4) pp. 497-503.

Eser, S., R.G. Jenkins, G. Wei, H.H. Schobert, and J.T. Joseph. 1991. High Temperature Swelling of Coal/Tetralin Mixtures in a High Pressure Microdilatometer. Fuel 70 (December 1991). pp. 1445-1455.

Folsom, B.A., T.M. Sommer, P.A. Engelhardt, and S. Freedman. 1996. Gas Reburning for NOx Control: A Boiler Durability Assessment. Proceedings of the American Power Conference, 58-II, Chicago, IL. pp. 842-852.

Friesen, W.I., and O.I. Ogunsola. 1994. Principal Component Analysis of Upgraded Canadian Coals. Fuel Processing Technology 38 pp. 139-151.

Friesen, W.I., and O.I. Ogunsola. 1995. Mercury Porosity of Upgraded Western Canadian Coals. Fuel 74(4) pp. 604-609.

Gabrielson, J.E., A.A. Lookman, J.P. Bionda, S.J. Nix. 1995. Results of NOx Retrofit of Kentucky Utilities Ghent 1 Tangentially Fired Unit. Proceedings of the 1995 International Joint Power Generation Conference. American Society of Mechanical Engineers, Minneapolis, MN. pp. 1035-1040.

Hill, Dwayne 1996. Power Magazine's summary report on Powerplant IT Conference. Information obtained from Internet under http://www.powermag.com/newtech.html dated $2 / 24 / 97$.

Hill, Dwayne. 1997. Personal communication by telephone on 17 March 1997, (608) 788-4000 ext. 424.

Jones, C. 1995a. T-fires Unit NOx Retrofit Gets Beachhead in South. Power 139(1). Jan. 1995. pp. 55-57.

Jones, C. $1995 b$ Utility Demo Confirms Performance of Latest T-fired NOx Control Techniques. Power 139(2), Feb. 1995. pp. 49-50.

Jones, C. 1997. Maladies of Low-NOx Firing Come Home to Roost. Power 141(1). Jan.-Feb. 1997. pp. 54-60.

Kambara, S., T. Takarada, M. Toyoshima, and K. Kato. 1995. Relation Between Functional Forms of Coal Nitrogen and NOx Emissions from Pulverized Coal Combustion. Fuel 74(9). pp. 1247-1253. 
Keleman, S.R., M.L. Gorbaty, and P.J. Kwiatek 1994. "Quantification of Nitrogen Forms in Argonne Premium Coals." Energy \& Fuels 8(4). pp. 896-906.

Krameric, B.A., and R.L. Rupinskas. 1995. Experience Modifying Power Plant Systems for Switching to Power River Basin (PRB) Coal. Proceedings of the American Power Conference, 58-II, Chicago, IL. pp. 842-852.

Lau, C.-W., and S. Niksa. 1993. Combustion and Flame 95 p. 1; cited in Niska and Cho 1996.

Leone, M. 1994. Washington Update. Power 138(2). February 1994. p. 7.

Leppälahti, J., P. Simell, and E. Kurkela. 1991. Catalytic Conversion of Nitrogen Compounds in Gasification Gas. Fuel Processing Technology 29 pp. 43-56.

Lin, Ping-Wha. 1996. Lin's Theory of Flux and Air Pollution Control. Proceedings of the American Power Conference, 58-II, Chicago, $\mathrm{LL}$.

McComas, M. and C. Morris. 1995. Fuel Switch Meets Clean Air Act and Reduces Power Cost 17\%. Proceedings of the American Power Conference, 57-II, Chicago, IL. pp. 1627-1632.

Maier, H., H. Spliethoff, A. Kicherer, A. Fingerle, and K.R.G. Hein. 1994. Effect of Coal Blending and Particle Size on NOx Emission and Burnout. Fuel 73(9). pp. 1447-1452.

Makansi, J. 1993. Special Report: Reducing NOx Emissions from Today's Power Plants. Power 137(5). May 1993. pp. 11-30.

Makansi, J. 1994a. SO2/NOx Control: Fine Tuning for Phase I Compliance. Power 138(3). March 1994.pp. 18-28.

Makansi, J. 1994b. New Supply Lines, Tools Keep Coal Switching in Forefront. Power 138(5). May 1994. pp. 41-48.

Makansi, J. 1996a. Process Optimization Aims for Closed-loop Control. Power 140(2). Feb. 1996. pp. 26-28.

Makansi, J. 1996b. Emissions Control. Power 140(3). March 1996. pp. 25-32.

Mori, H., K. Asami, and Y. Ohtsuka. 1996. Role of Iron Catalyst in Fate of Fuel Nitrogen during Coal Pyrolysis. Energy and Fuels 10(4). pp. 1022-1027.

Morris, E.L. and T.W. Sweeney. 1995. Controlled Flow, Split Flame Low-NOx Burner System Performance on a Tangentially Fired Boiler. Proceedings of the 1995 International Joint Power Generation Conference. American Society of Mechanical Engineers, Minneapolis, MN. pp. 69-74..

Niksa, S. and S. Cho. 1996. Conversion of Fuel nitrogen in the Primary Zones of Pulverized Coal Flames. Energy and Fuels 10(2). pp. 463-473. 
Nowok, J.W., S.A. Benson, M.L. Jones, and D.P. Kalmanovitch. 1990. Sintering Behavior and Strength Development in Various Coal Ashes. Fuel 69(8) pp. 1020-1028.

Offen, George, 1997. personal communication [February 27, 1997, at (415) 855 8942]

Ogunsola, O.I. 1993. Thermal Upgrading Effect on Oxygen Distribution in Lignite. Fuel Processing Technology. 34(1993). pp. 73-81.

Ohtsuka, Y., H. Mori, K. Nonaka, T. Watanabe, and K. Asami. 1993. Selective Conversion of Coal Nitrogen to $\mathrm{N}_{2}$ with Iron. Energy and Fuels 7(6) pp. 1095-1096.

Pease, B.R., A.A. Levasseur, and O.K. Chow. 1993. Fuel Switching: A Pilot-scale Approach to Boiler Performance Predictions. Energy \& Fuels. 7(6). pp. 768-773.

Penterson, C.A., and D.E. Dorman. 1995. Low-NOx Retrofit Problems and Solutions: A Joint Perspective. Proceedings of the 1995 International Joint Power Generation Conference. American Society of Mechanical Engineers, Minneapolis, MN. pp. 365-377.

Penterson, C.A. and X.A. Dorai. 1995. An Economical Solution for Reducing NOx Emissions from Cell Burner Boilers Firing Pulverized Coal. Proceedings of the American Power Conference, 57-II, Chicago, IL. pp. 1188-1193.

Pershing, D.W. and J.O.L. Wendt. 1979. Relative Contributions of Volatile Nitrogen and Char Nitrogen to NOx Emissions from Pulverized Coal Flames. Industrial and Engineering Chemistry Process Design and Development. 18 p. 60-67.

Reynolds, P.E., R.N. Hill, B.W. Jackson. 1995. Frank E. Ratts Station Fuel Switch and LowNOx Burner Retrofit Performance Testing Results. Proceedings of the 1995 International Joint Power Generation Conference. American Society of Mechanical Engineers, Minneapolis, MN. pp. 75-79.

Ross, D.S., B.H. Loo, D.S. Tse, and A.S. Hirschon. 1991. Hydrothermal Treatment and the Oxygen Functionalities in Wyodak Coal. Fuel 70(March) pp. 289-295.

Spliefthoff, H., U. Greul, H. Rüdiger, and K.R.G. Hein. Basic Effects on NOx Emissions in Air Staging and Reburning at a Bench-Scale Test Facility. Fuel 75(5). pp. 560-564.

Steitz, T.H., and R.W. Cole. 1996. Field Experience in Over 30,000 MW of Wall Fired Low NOx Installations. ASME International Joint Power Generation Conference, Houston, TX, October 1996.

Storm, R. 1993. Optimizing Combustion in Boilers with Low-NOx Burners. Power 137(10). October 1993. pp. 53-62.

Swanekamp, R. 1996. Fuel Management. Power 140(1). Jan. 1996. pp. 11-16. 
Thompson, E.E. G.H. Shiomoto, and F.P. Haumesser. 1996. Post-Retrofit Operating and NOx Emission Experience on Five Tangentially-fired Units. ASME International Joint Power Generation Conference, Houston, TX, October 1996.

Trego, P., E. Schultz, R. Klelsley, S. Gossard, P. Panera. 1995. PECO Energy's Cromby Unit \# 1: Challenges of Retrofitting Low-NOx Combustion Technology to a Single Wall Fired Boiler. Proceedings of the 1995 International Joint Power Generation Conference. American Society of Mechanical Engineers, Minneapolis, MN.

Tullin, C.J., S. Goel, A. Morihara, A.F. Sarofim, and J.M. Beér. 1993. NO and $\mathrm{N}_{2} \mathrm{O}$ Formation for Coal Combustion in a Fluidized Bed. Energy \& Fuels 7(6) pp. 796-802.

Varey, J.E., C.J. Hindnarsh, and K.M. Thomas. 1996. The Detection of Reactive Intermediates in the Combustion and Pyrolysis of Coals, Chars and Macerals. Fuel 75(2) pp. 164-176.

Wang, W.X., S.D. Brown, C.J. Hindmarsh, and K.M. Thomas. 1994. NOx Release and Reactivity of Chars from a Wide Range of Coals During Combustion. Fuel 73(9) pp. 1381-1388.

Wang, W., S.D. Brown, K.M. Thomas, and J.C. Crelling. 1994. Nitrogen Release from a Rank Series of Coals During Temperature Programmed Combustion. Fuel 73(3). pp. 341-347.

Wang, W.X., K.M. Thomas, H.Y. Cai, D.R. Dugwell, and R. Kandiyote. 1996. NO Release and Reactivity of Chars During Combustion: The Effect of Devolatilization Temperature and Heating Rate. Energy \& Fuels. 10(2). pp. 409-416.

Wendt, J.O.L. and Pershing, D.W. 1977. Physical Mechanisms Governing the Oxidation of Volatile Fuel Nitrogen in Pulverized Coal Flames. Combustion Science and Technology 16 pp. 111-121.

Williams, A., M. Pourkashanian, P. Bysh and J. Norman. 1994. Modeling of Coal Combustion in low-NOx p.f. Flames. Fuel 73(7). p. 1006-1019.

Willson, W.G., S.A. Farnum, and G.G. Baker. 1987. Low-Rank Coal Slurries for Gasification. Fuel Processing Technology 15 pp. 157-172.

Wójtowicz, M.A., J.R. Pels, and J.A. Moulijn. 1993. Combustion of Coal as a Source of $\mathrm{N}_{2} \mathrm{O}$ Emission. Fuel Processing Technology 34(1993) pp. 1-71.

Wójtowicz, M.A., J.R. Pels, and J.A. Moulijn. 1995. The Fate of Nitrogen Functionalities in Coal During Pyrolysis and Combustion. Fuel 74(4) pp. 507-516.

Yang, M.H. and I. K. Puri. 1993. NOx Formation in Stretched Premixed Flames Established Far from Extinction. Fuel 72(4). pp. 489-495.

Zabarnick, S. 1992. A Comparison of $\mathrm{CH}_{4} / \mathrm{NO} / \mathrm{O}_{2}$ and $\mathrm{CH}_{4} / \mathrm{N}_{2} \mathrm{O}$ Flames by LIF Diagnostics and Chemical Kinetic Modeling. Combustion Science and Technology 83 p. 115. 
Zygarlicke, C.J., D.P. McCollor, D.L. Torman, T.F. Wall, R.P. Gupta, and H. Raznei. 1995. A Comparison of Ash Produced under Conventional and Low-NOx Combustion Conditions. Proceedings of the 1995 International Joint Power Generation Conference. American Society of Mechanical Engineers, Minneapolis, MN. pp. 449-462. 